Prepared in cooperation with the Carson Water Subconservancy District and Douglas County

\title{
In-Situ Arsenic Remediation in Carson Valley, Douglas County, West-Central Nevada
}

Scientific Investigations Report 2010-5161 



\section{In-Situ Arsenic Remediation in Carson Valley, Douglas County, West-Central Nevada}

By Angela P. Paul, Douglas K. Maurer, Kenneth G. Stollenwerk, and Alan H. Welch

Prepared in cooperation with the Carson Water Subconservancy District and Douglas County

Scientific Investigations Report 2010-5161

U.S. Department of the Interior

U.S. Geological Survey 


\title{
U.S. Department of the Interior \\ KEN SALAZAR, Secretary
}

\section{U.S. Geological Survey \\ Marcia K. McNutt, Director}

\section{U.S. Geological Survey, Reston, Virginia: 2010}

\author{
For more information on the USGS — the Federal source for science about the Earth, its natural and living resources, \\ natural hazards, and the environment, visit http://www.usgs.gov or call 1-888-ASK-USGS \\ For an overview of USGS information products, including maps, imagery, and publications, \\ visit http://www.usgs.gov/pubprod \\ To order this and other USGS information products, visit http://store.usgs.gov
}

Any use of trade, product, or firm names is for descriptive purposes only and does not imply endorsement by the U.S. Government.

Although this report is in the public domain, permission must be secured from the individual copyright owners to reproduce any copyrighted materials contained within this report.

Suggested citation:

Paul, A.P., Maurer, D.K., Stollenwerk, K.G., and Welch, A.H., 2010, In-situ arsenic remediation in Carson Valley, Douglas County, west-central Nevada: U.S. Geological Survey Scientific Investigations Report 2010-5161, 24 p. 


\section{Contents}

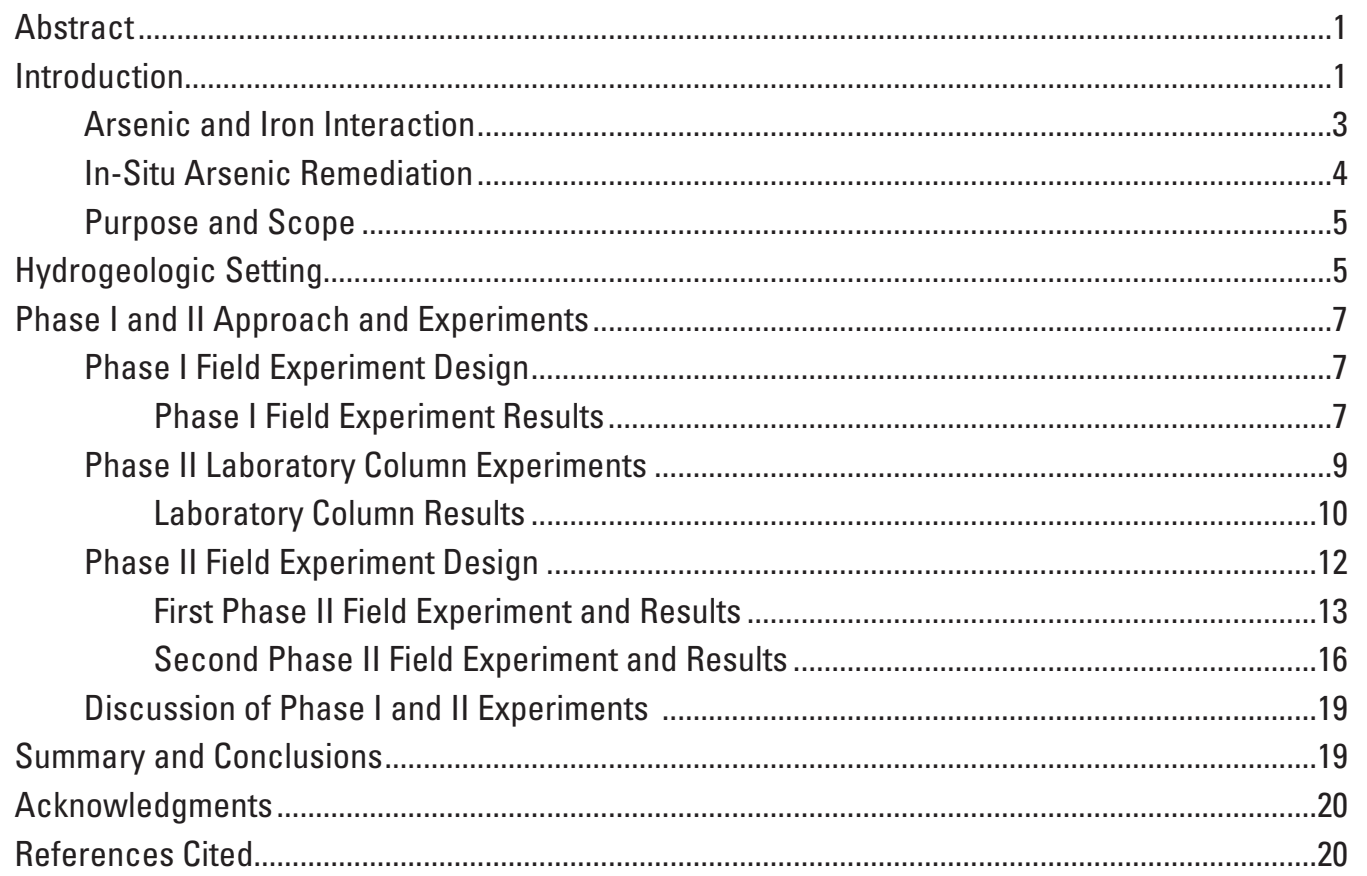




\section{Figures}

Figure 1. Map showing arsenic concentrations in selected wells and remediation test well locations, Carson Valley, Douglas County, Nevada

Figure 2. Diagram showing lithology of core obtained November 2007 when drilling Arsenic 2-inch (As-2) and Arsenic 6-inch (As-6) wells for Phase II, in-situ arsenic remediation experiments, Douglas County, Nevada, June and October 2008

Figure 3. Graphs showing concentrations of arsenic and iron and manganese withdrawn from the EXP-2 shallow well after treatment with low, moderate, and high iron concentrations at $\mathrm{pH}$ values ranging from 5.3 to 5.6 during Phase 1, in-situ arsenic remediation experiments, Douglas County, Nevada, September 2006 ...... 8

Figure 4. Graphs showing concentrations of arsenic and iron and manganese withdrawn from the EXP-2 deep well after treatment with low, moderate, and high iron concentrations at $\mathrm{pH}$ values ranging from 5.3 to 6.0 , during Phase I, in-situ arsenic remediation experiments, Douglas County, Nevada, September 2006 .......

Figure 5. Graph showing arsenic concentrations in leachate and source water from column experiments, Douglas County, Nevada

Figure 6. Graph showing pH of leachate from column experiments, Douglas County, Nevada

Figure 7. Graph showing manganese concentrations in leachate from column experiments, Douglas County, Nevada

Figure 8. Schematic diagrams of treatment and sampling ports for Phase II in-situ arsenic remediation, Douglas County, Nevada

Figure 9. Graphs showing measured pH and alkalinity during Phase II experiment No. 1, in-situ arsenic remediation, Douglas County, Nevada, June 23, 2008

Figure 10. Graph showing remediation of arsenic during and after Phase II experiment No. 1, in-situ arsenic remediation, Douglas County, Nevada, June 23-26, 2008

Figure 11. Graphs showing groundwater flow through activated carbon filters and air-lift rates during the second Phase II field experiment, in-situ arsenic remediation, Douglas County, Nevada, October 16, 2008

\section{Tables}

Table 1. Concentrations of arsenic, arsenic speciation, iron, $\mathrm{pH}$, and dissolved oxygen in water from wells at or near the arsenic remediation site, Douglas County, November 2005

Table 2. Source-water composition for laboratory column experiments using core material from wells drilled as part of the Phase II, in-situ arsenic remediation study, Douglas County, Nevada

Table 3. Summary of treatment and concentrations of substances used during first Phase II field experiment No. 1, in-situ remediation of arsenic remediation, Douglas County, Nevada, June 23, 2008

Table 4. Volumes of groundwater through treatment system during first Phase II field experiment No. 1, in-situ arsenic remediation, Douglas County, Nevada, June 23,2008

Table 5. Concentration of various arsenic species determined for samples collected during first Phase II field experiment No. 1, in-situ arsenic remediation, Douglas County, Nevada, June 23-24, 2008 


\section{Conversion Factors, Datums, and Abbreviations and Acronyms}

Conversion Factors

\begin{tabular}{|c|c|c|}
\hline Multiply & By & To obtain \\
\hline \multicolumn{3}{|c|}{ Length } \\
\hline inch (in.) & 2.54 & centimeter $(\mathrm{cm})$ \\
\hline foot $(\mathrm{ft})$ & 0.3048 & meter $(\mathrm{m})$ \\
\hline \multicolumn{3}{|c|}{ Area } \\
\hline square foot $\left(\mathrm{ft}^{2}\right)$ & 0.09290 & square meter $\left(\mathrm{m}^{2}\right)$ \\
\hline \multicolumn{3}{|c|}{ Volume } \\
\hline gallon (gal) & 3.785 & liter $(\mathrm{L})$ \\
\hline cubic foot $\left(\mathrm{ft}^{3}\right)$ & 7.48 & gallon (gal) \\
\hline acre-foot (acre-ft) & 1,233 & cubic meter $\left(\mathrm{m}^{3}\right)$ \\
\hline \multicolumn{3}{|c|}{ Flow rate } \\
\hline acre-foot per year (acre-ft/yr) & 1,233 & cubic meter per year $\left(\mathrm{m}^{3} / \mathrm{yr}\right)$ \\
\hline gallon per minute (gal/min) & 0.06309 & liter per second $(\mathrm{L} / \mathrm{s})$ \\
\hline \multicolumn{3}{|c|}{ Mass } \\
\hline pound, avoirdupois (lb) & 2.205 & kilogram $(\mathrm{kg})$ \\
\hline \multicolumn{3}{|c|}{ Pressure } \\
\hline atmosphere, standard (atm) & 101.3 & kilopascal $(\mathrm{kPa})$ \\
\hline \multicolumn{3}{|c|}{ Density } \\
\hline pound per cubic foot $\left(\mathrm{lb} / \mathrm{ft}^{3}\right)$ & 16.02 & kilogram per cubic meter $\left(\mathrm{kg} / \mathrm{m}^{3}\right)$ \\
\hline pound per cubic foot $\left(\mathrm{lb} / \mathrm{ft}^{3}\right)$ & 0.01602 & gram per cubic centimeter $\left(\mathrm{g} / \mathrm{cm}^{3}\right)$ \\
\hline pound per cubic foot $\left(\mathrm{lb} / \mathrm{ft}^{3}\right)$ & 0.01302 & grams per milliliter $(\mathrm{g} / \mathrm{mL})$ \\
\hline
\end{tabular}

Specific conductance is given in microsiemens per centimeter at 25 degrees Celsius $(\mu \mathrm{S} / \mathrm{cm}$ at $\left.25^{\circ} \mathrm{C}\right)$.

Concentrations of chemical constituents in water are given either in milligrams per liter (mg/L) or micrograms per liter $(\mu \mathrm{g} / \mathrm{L})$.

To convert grams per milliliter ( $\mathrm{gm} / \mathrm{mL}$ ) to milligrams per milliliter, multiply by 1,000 .

Datums

Vertical coordinate information is referenced to the North American Vertical Datum of 1988 NAVD 88).

Horizontal coordinate information is referenced to the North American Datum of 1983 (NAD 83). Altitude, as used in this report, refers to distance above the vertical datum. 
Abbreviations and Acronyms

\begin{tabular}{ll}
\hline $\begin{array}{c}\text { Abbreviation } \\
\text { or acronym }\end{array}$ & \multicolumn{1}{c}{ Meaning } \\
\hline HFO & hydrous ferric oxide \\
ka & kiloannum; unit of time equal to one thousand years \\
MCL & maximum contaminant level \\
SAP & South Airport Production well \\
USEPA & U.S. Environmental Protection Agency \\
USGS & U.S. Geological Survey \\
\hline
\end{tabular}




\title{
In-Situ Arsenic Remediation in Carson Valley, Douglas County, West-Central Nevada
}

\author{
By Angela P. Paul, Douglas K. Maurer, Kenneth G. Stollenwerk, and Alan H. Welch
}

\section{Abstract}

Conventional arsenic remediation strategies primarily involve above-ground treatment that include costs involved in the disposal of sludge material. The primary advantages of in-situ remediation are that building and maintaining a large treatment facility are not necessary and that costs associated with the disposal of sludge are eliminated. A two-phase study was implemented to address the feasibility of in-situ arsenic remediation in Douglas County, Nevada.

Arsenic concentrations in groundwater within Douglas County range from 1 to 85 micrograms per liter. The primary arsenic species in groundwater at greater than $250 \mathrm{ft}$ from land surface is arsenite; however, in the upper $150 \mathrm{ft}$ of the aquifer arsenate predominates. Where arsenite is the primary form of arsenic, the oxidation of arsenite to arsenate is necessary. The results of the first phase of this investigation indicated that arsenic concentrations can be remediated to below the drinking-water standard using aeration, chlorination, iron, and $\mathrm{pH}$ adjustment. Arsenic concentrations were remediated to less than 10 micrograms per liter in groundwater from the shallow and deep aquifer when iron concentrations of 3-6 milligrams per liter and $\mathrm{pH}$ adjustments to less than 6 were used. Because of the rapid depletion of dissolved oxygen, the secondary drinking-water standards for iron (300 micrograms per liter) and manganese (100 micrograms per liter) were exceeded during treatment. Treatment was more effective in the shallow well as indicated by a greater recovery of water meeting the arsenic standard.

Laboratory and field tests were included in the second phase of this study. Laboratory column experiments using aquifer material indicated the treatment process followed during the first phase of this study will continue to work, without exceeding secondary drinking-water standards, provided that groundwater was pre-aerated and an adequate number of pore volumes treated. During the 147-day laboratory experiment, no decrease in flow through the column was observed. The primary mechanism of arsenic removal is through coprecipitation with iron oxide.

Calculations based on the results of the column experiments and assuming 10 and 30 percent porosity indicated that treatment of approximately
237,000-714,000 gallons of water would be required in order to remediate arsenic concentrations to less than 10 micrograms per liter. During the first second-phase field experiment, effective injection of treated groundwater back into the aquifer was prevented due to clogging likely caused by entrained gases and the fine texture (sand, clay, and gravel) of the aquifer sediments. Because of the overflow of treated water from the injection wells, only 3,760 gallons of treated water were injected. Immediately upon terminating this first experiment, no arsenic remediation was apparent. However, approximately 24 hours after terminating the experiment arsenic concentrations in groundwater collected from one of the injection wells showed a decrease from about 30 to 15 micrograms per liter, indicating that some remediation had taken place. In agreement with the laboratory-column experiments, pre-aeration prevented the exceedence of the secondary drinking-water standards for iron and manganese. Because of complications associated with system hydraulics, no additional experiments were performed.

\section{Introduction}

In January 2001, the U.S. Environmental Protection Agency (USEPA) lowered the maximum contaminant level (MCL) for drinking water from 50 to $10 \mu \mathrm{g} / \mathrm{L}$ (U.S. Environmental Protection Agency, 2001a, 2001b). Because of this change, many areas in the United States that previously met the drinking-water standard now must remove arsenic from the water and water purveyors are searching for new cost-effective methods. Arsenic is commonly associated with volcanic and alluvial/lacustrine sedimentary deposits and is one of the most common contaminants in groundwater in the western United States (Welch and others, 1988; Walker and others, 2008). Arsenic concentrations in the northeastern part of Carson Valley, Douglas County, Nevada, are greater than the new arsenic standard (fig. 1). Douglas County and the Carson Water Subconservancy District are considering the development of a well field in the valley near the airport to treat the water to remove arsenic. Other methods, as well as those considered conventional, for the removal of arsenic are being considered, including below-ground (in-situ) treatment. 


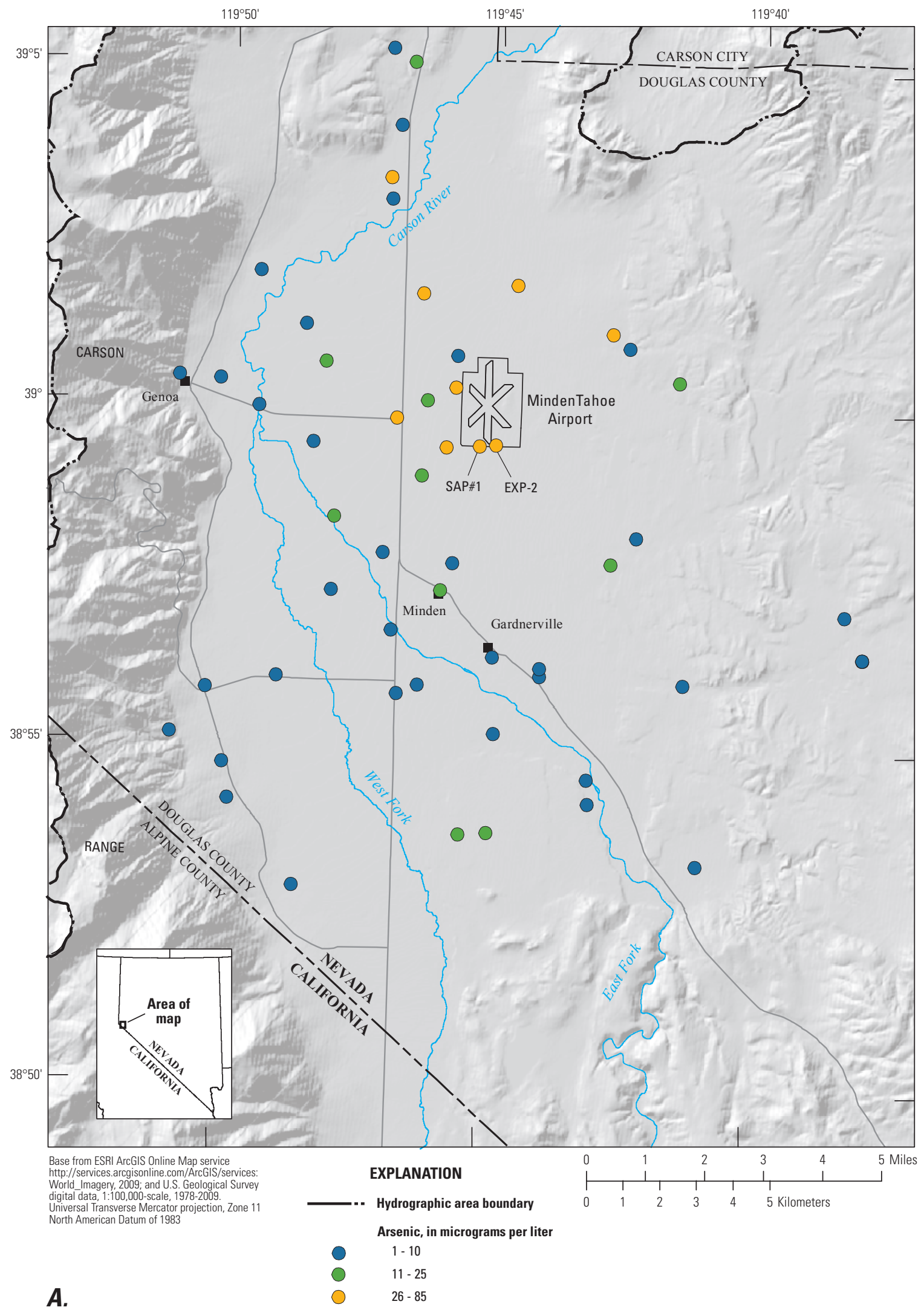

Figure 1. Arsenic $(A)$ concentrations in selected wells and $(B)$ remediation test well locations, Carson Valley, Douglas County, Nevada. 


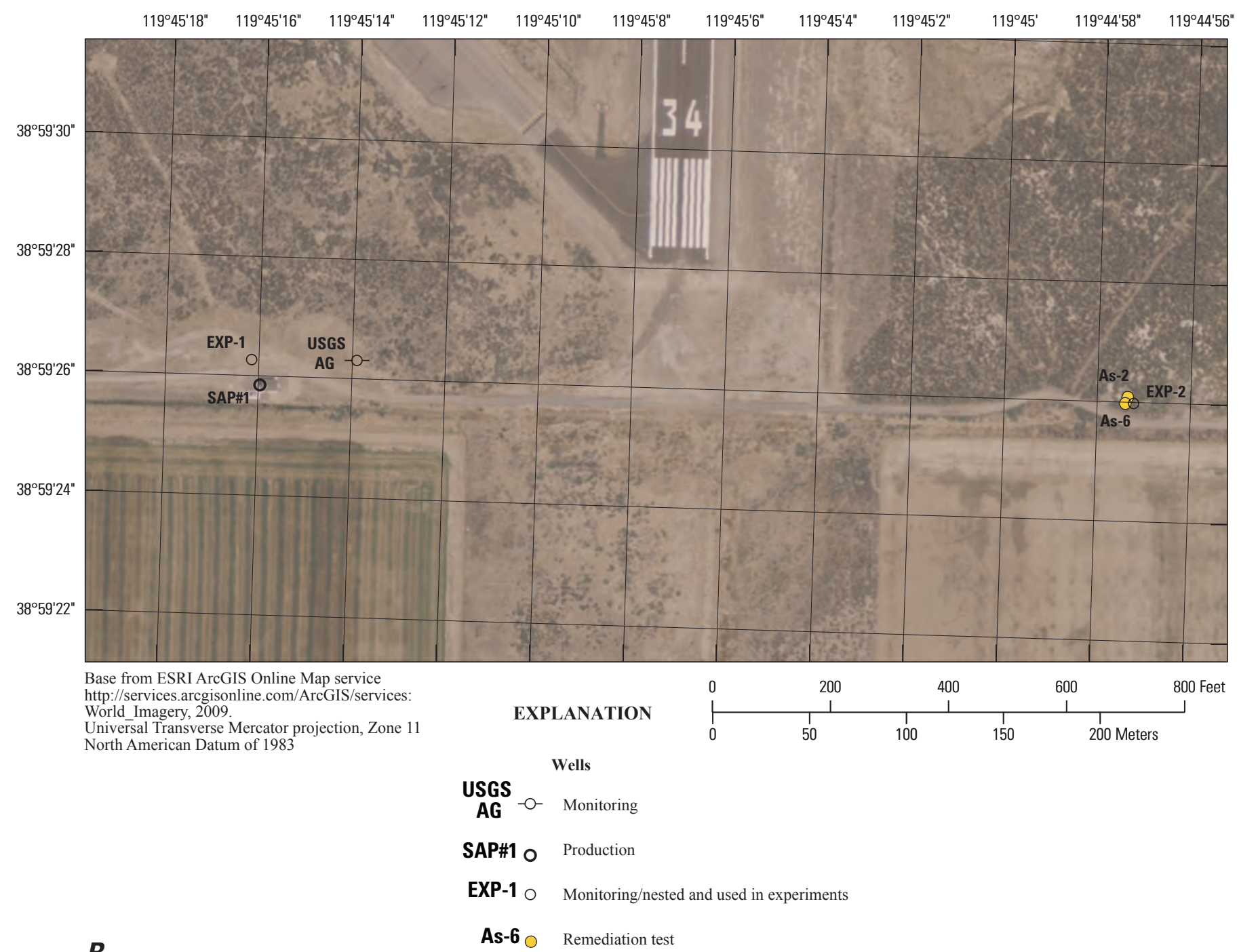

Figure 1. Continued.

Conventional methods for treating drinking-water, including point-of-use by reverse osmosis (Walker and others, 2008), above-ground iron or alumina coprecipitation, or both (Cadena and Kirk, 1995; Kartinen and Martin, 1995), and ionexchange (Kartinen and Martin, 1995), have been investigated for effectiveness in removing arsenic. A potentially costeffective alternative to removing arsenic using traditional above-ground treatments is lowering arsenic concentrations within the aquifer by a process called "in-situ" removal. In this process, metals are retained in the aquifer as a coprecipitate with metal oxides or sulfides (Rott, 1990; Mettler and others, 2001; Druhan and others, 2008). Arsenic retention is enhanced by increasing the adsorption capacity of the aquifer sediments by adding iron, adjusting $\mathrm{pH}$, or both.

\section{Arsenic and Iron Interaction}

The geochemical cycling of arsenic is largely controlled by sorption reactions associated with the presence of aluminum, iron, and manganese oxides (Anderson and others, 1976; Oscarson and others, 1981; De Vitre and others, 1991). In natural systems, adsorption and coprecipitation often are indistinguishable and, as a result, these processes often are used interchangeably (Drever, 1988). Generally, the same geochemical conditions that optimize the adsorption of arsenic onto iron oxide ( $\mathrm{pH}$ below 8 , adequate dissolved oxygen, and predominance of arsenate) optimize their coprecipitation. In areas enriched in arsenic, high concentrations of dissolved arsenic often are associated with groundwater with alkaline $\mathrm{pH}$ because the adsorption of arsenic to metal oxides decreases with increasing $\mathrm{pH}$ (Edwards, 1994). 
In natural waters, inorganic arsenic typically occurs as two species: arsenite $(\mathrm{As}(\mathrm{III}))$ or arsenate $(\mathrm{As}(\mathrm{V}))$. Under more oxidizing conditions $\mathrm{As}(\mathrm{V})$ is the primary arsenic species whereas under reducing conditions As(III) predominates (Ferguson and Gavis, 1972). ${ }^{1}$ Generally, As(III) is more mobile in aqueous systems than $\mathrm{As}(\mathrm{V})$ (Masscheleyn and others, 1991; Chiu and Hering, 2000; Nordstrom and Archer, 2003), mostly because of the neutral charge of this species at $\mathrm{pH}$ ranges typically encountered in the natural environment (Ferguson and Gavis, 1972). In systems with a $\mathrm{pH}$ near 7, the negatively-charged $\mathrm{As}(\mathrm{V})$ readily adsorbs to positively-charged metal oxides, such as aluminum and iron. The initial adsorption of arsenic onto iron oxides is relatively fast, typically within a few minutes to hours (Fuller and others, 1993; Raven and others, 1998); however, arsenic adsorption can continue during prolonged exposure to the oxide (Fuller and others, 1993). Under similar environmental conditions, As(III) has limited affinity for metal oxides. When coprecipitating arsenic with iron oxide, therefore, converting $\mathrm{As}(\mathrm{III})$ to $\mathrm{As}(\mathrm{V})$ is necessary to enhance the reaction (Rott and Friedle, 1999). In alkaline waters, As(V) generally becomes increasingly mobile as a result of the repulsion between the negatively charged metal oxide surfaces and arsenic anion (Anderson and others, 1976). Theoretically, at $\mathrm{pH}$ ranges less than 8.0, the surface charge of iron oxide is positive, which enhances the association between the arsenate anion and oxide surface (Raven and others, 1998; Chui and Hering, 2000; Zeng and others, 2008).

\section{In-Situ Arsenic Remediation}

Although a relatively new treatment in the United States, in-situ treatment for the removal of arsenic, iron, or manganese, or combination thereof, has been successfully applied to municipal-supply wells for several years in some parts of Europe (Rott, 1990; Mettler and others, 2001). In the United States, in-situ remediation of other trace-elements, such as chromium, is gaining regulatory acceptance (Grosse and others, 2000). In-situ remediation is generally thought to be less expensive than above-ground treatment because of the relatively lower costs associated with operation and maintenance of in-situ methods (Grosse and others, 2000; Water Research Commission South Africa, 2004). Costs associated with the in-situ removal of plume-related chromium using techniques similar to those used in this study varied depending on site-specific considerations and ranged from about $\$ 250,000$ to $\$ 1,677,800$ (Brown and others, 1998; Rouse and others, 1999; Grosse and others, 2000). Although sitespecific considerations increased the general costs associated with the above-ground arsenic treatment plant in Fallon, Nevada, the cost for building this facility was $\$ 19$ million (White, 2009). Rott and Friedle (1999) achieved arsenic removal efficiencies greater than 10 , meaning for each volume of treated water injected, 10 volumes of water with arsenic concentrations less than $10 \mu \mathrm{g} / \mathrm{L}$ were withdrawn. Samples collected during an in-situ treatment of arsenic in a fractured basalt aquifer in Churchill County, Nevada, by reduction of $\mathrm{pH}$ and addition of iron to increase the adsorption capacity of the aquifer material, showed a 50 percent reduction in arsenic concentration (Welch and others, 2003).

Commonly expressed concerns associated with in-situ remediation practices include precipitation of iron and arsenic that may decrease aquifer permeability, or increase concentrations of arsenic or other trace elements to values greater than before remediation was started. However, published research has shown that during in-situ remediation, iron oxide does not accumulate near the well-screen, but moves out into the aquifer (Appelo and others, 1999; Mettler and others, 2001; Mettler, 2002; Appelo and deVet, 2003). Additionally, the mass of iron and arsenic removed are small compared with the mass of the aquifer material likely to be affected. For example, the aquifer within $200 \mathrm{ft}$ surrounding a typical well in northeast Carson Valley contains about 2.4 $\times 10^{9} \mathrm{~kg}$ of sediment ${ }^{2}$ (Welch and others, 2008). The amount of iron that would be added from the injection of water for a period of 100 years would be about 0.1 percent of this mass. ${ }^{3}$ In comparison to the mass of the aquifer material, the small amount of additional mass resulting from the coprecipitation of arsenic and iron near a production well make the potential of significantly lowering well production unlikely (Mettler and others, 2001).

The amount of arsenic introduced to the same mass of aquifer material would be much less than the amount of iron added. If removal of $33 \mu \mathrm{g} / \mathrm{L}$ of arsenic were complete, then the amount of arsenic retained in the aquifer would result in a two-fold increase of the arsenic concentration in the sediment. ${ }^{4}$ Most of the arsenic is expected to be associated with the iron oxide phase, which becomes less susceptible to reductive dissolution over time because of recrystallization (Jones and others, 2000; Zobrist and others, 2000; Mettler and others, 2001; Ford, 2002; Violante and others, 2007).

\footnotetext{
${ }^{1}$ For a definition of what constitutes an "oxidizing" or "reducing" environment the reader is directed to the following references: Hem, 1985 (p. 20-22); Drever, 1988 (p. 281-304); Langmuir, 1997 (p. 403-430).

${ }^{2}$ Assuming (1) a density of $2.6 \mathrm{gm} / \mathrm{cm}^{3}$, approximately the density of quartz and feldspar, (2) a porosity of 0.3 , and (3) an aquifer thickness of about $360 \mathrm{ft}$, as indicated by drilling logs for selected production wells in northeastern Douglas County.

${ }^{3}$ Assuming (1) a flow rate of $1,800 \mathrm{gal} / \mathrm{min}$ and (2) an iron concentration of $7.5 \mathrm{mg} / \mathrm{L}$.

${ }^{4}$ Assuming an arsenic content of the pre-treatment sediment is equal to the geometric mean for the United States of $5.2 \mathrm{mg} / \mathrm{kg}$ for surficial sediments (Shacklette and Boerngen, 1984).
} 


\section{Purpose and Scope}

This report, prepared in cooperation with the Carson Water Subconservancy District and Douglas County, presents the results of a two-phase experiment evaluating the potential for in-situ remediation to reduce arsenic concentrations in groundwater from Douglas County, Nevada. This evaluation incorporates laboratory column and field experiments summarizing lithologic data from wells drilled and results of field and laboratory experiments during November 2005 to October 2008.

\section{Hydrogeologic Setting}

Carson Valley is in northwestern Nevada east of the Sierra Nevada Mountains. The alluvial sediments of the Carson Valley are composed of weathered material from plutonic, mafic and intermediate volcanic, meta-volcanic, and metasedimentary rocks (Welch, 1994; Welch and others, 2008). Mineralogic analysis of aquifer material using X-ray diffraction showed the aquifer sediments were composed of granodiorite, as indicated by varying amounts of quartz and plagioclase (John McCormack, Nevada Bureau of Mines and Geology, written commun., May 2008). The aquifer materials consisted of interbedded layers of gravel and coarse sand, clay and gravel, and clay ranging in thickness from 10 to $40 \mathrm{ft}$. The lithology associated with the screened interval at about 290 $335 \mathrm{ft}$ below land surface consisted of sand, clay, and gravel (fig. 2). The estimated age of the sediments in the aquifer near the wells used in these experiments is about 200-500 ka (Welch and others, 2008).
From 1971 to 2000, valley floor precipitation averaged about 7.9 in. (Maurer and Halford, 2004). As the Carson River flows through the Carson Valley, its flow is diverted through natural and man-made channels for flood irrigation of pasture grasses and alfalfa. Annual streamflow loss through the valley from 1990 to 2000 was estimated at 75,000 acre-ft/yr (Maurer and others, 2008). Most streamflow losses from the Carson River are consumed by irrigated crops and maintain a shallow water depth of less than $5 \mathrm{ft}$ below land surface within the valley (Maurer and others, 2008; Welch and others, 2008). Although the valley is irrigated for alfalfa, vegetation near the in-situ remediation experiments is mostly native rabbitbrush and sage.

Generally, arsenic concentrations near the Minden-Tahoe Airport ranged from about 28 to $38 \mu \mathrm{g} / \mathrm{L}$ except in samples collected from a shallow ( $25 \mathrm{ft}$ deep) well, USGS AG, which contained about $85 \mu \mathrm{g} / \mathrm{L}$ (fig. $1 B$, table 1). The predominant arsenic species is $\mathrm{As}(\mathrm{V})$ in wells screened in the upper $150 \mathrm{ft}$ of the aquifer, indicating conditions oxidizing to arsenic, whereas the predominant arsenic species is As(III) in wells screened below about $300 \mathrm{ft}$, indicating reducing conditions. The predominant arsenic species from the SAP\#1 well is As(III), although the well is screened from 150 to $405 \mathrm{ft}$, suggesting that most production is from the lower part of the screened interval. Detailed descriptions of sediments made during well installation describe color changes generally from brown to olive green, gray, and black at depths greater than about $150 \mathrm{ft}$ (ECO:LOGIC Engineering, 2003). These changes in color were additional evidence of oxidizing conditions at depths above about $150 \mathrm{ft}$ and reducing conditions below $150 \mathrm{ft}$. Iron concentrations in water samples are less than detection (less than $6 \mu \mathrm{g} / \mathrm{L}$ ) for all wells, except the 25 -ft USGS AG well $(12 \mu \mathrm{g} / \mathrm{L})$, and groundwater contained dissolved-oxygen concentrations less than $1 \mathrm{mg} / \mathrm{L}$.

Table 1. Concentrations of arsenic, arsenic speciation, iron, $\mathrm{pH}$, and dissolved oxygen in water from wells at or near the arsenic remediation site, Douglas County, November 2005.

[Abbreviations: SAP, South Airport Production well; USGS, U.S. Geological Survey; ft, foot; $\mu \mathrm{g} / \mathrm{L}$, microgram per liter; mg/L, milligram per liter; <, less than]

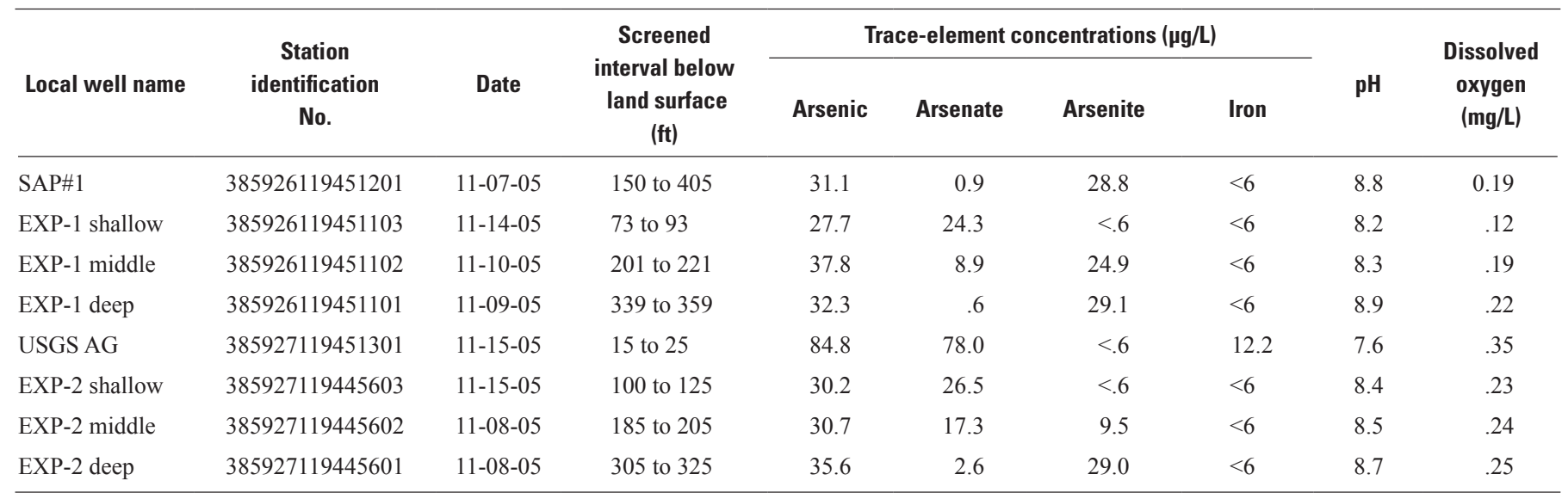




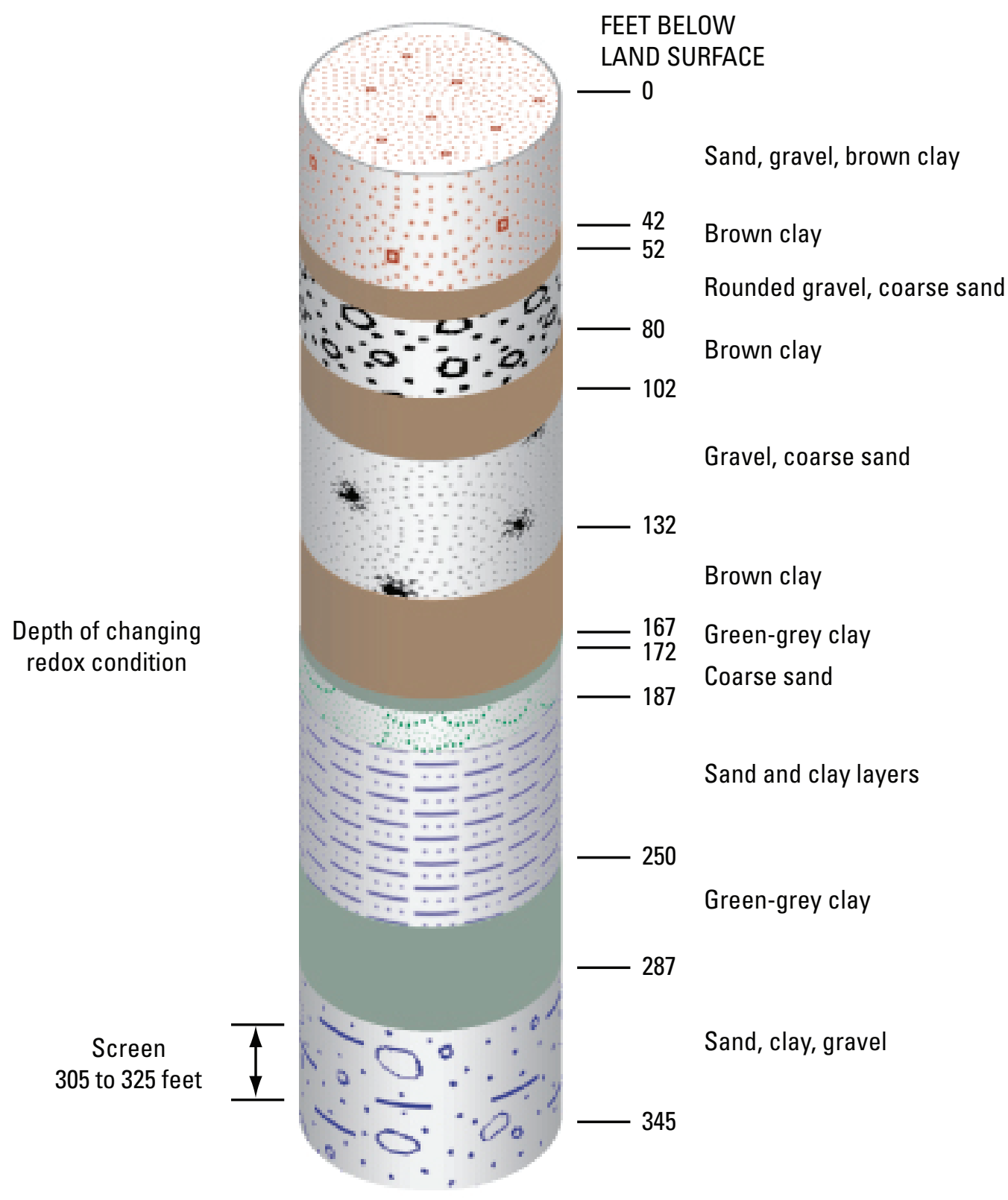

Figure 2. Lithology of core obtained November 2007 when drilling Arsenic 2-inch (As-2) and Arsenic 6-inch (As-6) wells for Phase II, in-situ arsenic remediation experiments, Douglas County, Nevada, June and October 2008. 


\section{Phase I and II Approach and Experiments}

The approach included (1) oxidation by aeration and chlorination of water pumped from the aquifer, (2) addition of acid to lower the $\mathrm{pH}$, (3) addition of iron to coprecipitate with arsenic and enhance aquifer adsorption properties, (4) injection of the treated water back into the aquifer, and (5) withdrawal of water from either the same well or adjacent well(s) for evaluation of the effectiveness of in-situ remediation. Aeration of the pumped water is needed as a source of oxygen for the formation of iron oxides. Unfortunately, the conversion of As(III) to As(V) by oxygen is slow (Eary, 1987; Lowry and Lowry, 2002) and can take months to years (Stollenwerk, 2003). Alternatively, chlorine is an effective oxidizer of arsenite (Frank and Clifford, 1986), but its use as an oxidant requires the removal of free chlorine prior to injection to avoid formation of carcinogenic disinfection by-products. In these in-situ experiments, the reduced form of iron, ferrous iron [Fe(II)], was used as the source of iron. Conceptually, the injected $\mathrm{Fe}(\mathrm{II})$ travels through the aquifer reacting with oxygen and becomes ferric iron, [Fe(III)], at which point it precipitates with arsenic from the groundwater onto aquifer materials (Rott and Friedle, 1999). Removal efficiency was calculated by dividing the volume of remediated water (with concentrations of arsenic less than 10 micrograms per liter) recovered by the volume of groundwater treated.

\section{Phase I Field Experiment Design}

The phase I experiment was designed to evaluate the effectiveness of in-situ arsenic remediation in Carson Valley at the south end of the Minden-Tahoe airport where production well SAP \#1 produces water with arsenic concentrations exceeding the drinking-water standard (fig. 1A). Phase I work included sampling of existing wells and field experiments in 2006 (Welch and others, 2008). Samples were collected from eight wells with varying depths near the remediation site including SAP\#1 production well; USGS-AG well, a 25 - $\mathrm{ft}$ deep monitoring well about $200 \mathrm{ft}$ northwest of SAP\#1; and three nested piezometers (one each representing shallow, middle, and deep) at EXP-1 and EXP-2 well sites (fig. 1B, table 1). EXP-1 and EXP-2 are located about $60 \mathrm{ft}$ north and $1,600 \mathrm{ft}$ east of SAP\#1, respectively.

Water was piped from the SAP\#1 well to the EXP-2 shallow and deep wells. The water from SAP\#1 was chlorinated at the well head by Douglas County with free chlorine concentrations in the treatment stream ranging from 0.4 to $0.7 \mathrm{mg} / \mathrm{L}$, as determined using a HACH DR890 field meter (HACH, 2000). Using a diffuser about $100 \mathrm{ft}$ from the SAP\#1 well head, air was injected into the pipeline attaining dissolved-oxygen concentrations of 9 to $11 \mathrm{mg} / \mathrm{L}$ before reaching the EXP-2 wells. A series of in-line valves at the EXP-2 wells were used to remove excess air from the injection water and a $2-\mathrm{ft}^{3}$ activated-carbon filter was used to remove chlorine prior to additional treatment and injection. After free chlorine was removed, hydrochloric acid and a ferrous chloride were added to reduce groundwater $\mathrm{pH}$ to between 4.5 and 6.5 and increase iron concentration.

The experiments consisted of injecting water with different iron concentrations and $\mathrm{pH}$ into the EXP-2 shallow and deep wells for periods of about 1 hour. Following injection and a reaction period of 1-2 hours, water was withdrawn from the well. This cycle was repeated several times because other studies have shown that efficiency increases with time (Rott and Friedle, 1999; Appelo and deVet, 2003). Water was withdrawn for periods of 1.5-4 hours until $\mathrm{pH}$ and specific conductance values reached pre-treatment conditions. Injection and withdrawal rates were about $5-6 \mathrm{gal} / \mathrm{min}$. During withdrawal, water was sampled to determine changes in concentrations of arsenic and other constituents. All samples were analyzed by the USGS National Water Quality Laboratory and Geologic Division, Denver, Colorado.

\section{Phase I Field Experiment Results}

Phase I experiments used iron concentrations ranging from 0.37 to $6.4 \mathrm{mg} / \mathrm{L}$, and $\mathrm{pH}$ values from 5.3 to 6.0 . Experiments using the low iron concentration $(0.37 \mathrm{mg} / \mathrm{L})$ removed little arsenic, whereas the high iron concentration $(6.4 \mathrm{mg} / \mathrm{L})$ reduced arsenic concentrations to as low as 1 $\mu \mathrm{g} / \mathrm{L}$ in the shallow well and as low as $5.7 \mu \mathrm{g} / \mathrm{L}$ in the deep well (figs. 3 and 4 ). In the shallow and deep wells, removal efficiency of groundwater with arsenic concentrations at or less than $10 \mu \mathrm{g} / \mathrm{L}$ ranged from 0 to 1.9 and from 0 to 0.5 , respectively. The experiments showed that arsenic removal was greater in the shallower well where the primary form of arsenic, prior to chlorination, was $\operatorname{As}(\mathrm{V})$ indicating a more oxidizing environment than in the deep well where As(III) predominated. This difference in redox condition was further indicated by the slower decline in dissolved-oxygen concentration during withdrawal of water from the shallow well compared to the deep well (Welch and others, 2008).

After treatment using the shallow well, arsenic concentration was less than drinking-water standard during the first hour of pumping using moderate $(3.3 \mathrm{mg} / \mathrm{L})$ and high $(6.4 \mathrm{mg} / \mathrm{L})$ iron treatment (fig. 3). The volumes of treated water withdrawn during these treatments were 406-554 gal, indicating removal efficiencies of 1.0 and 1.9 , respectively. Although arsenic concentrations were less than $10 \mu \mathrm{g} / \mathrm{L}$ during the first hour of pumping, the moderate to high iron treatments resulted in iron concentrations greater than the secondary drinking-water standard of $300 \mu \mathrm{g} / \mathrm{L}$. Iron concentrations generally decreased to less than detection $(50 \mu \mathrm{g} / \mathrm{L})$ after about one hour of withdrawal. Iron concentrations were below 

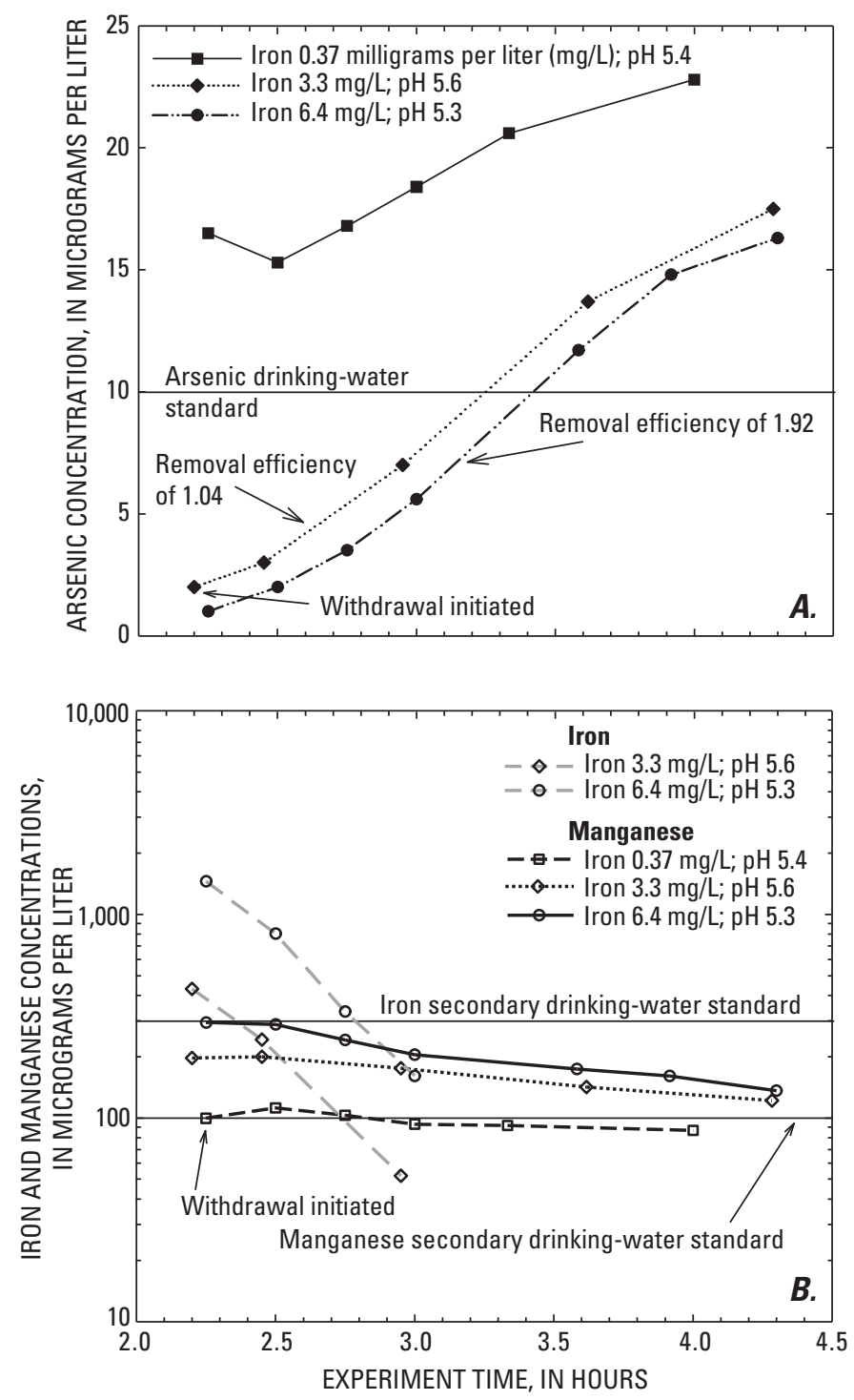

Figure 3. Concentrations of $(A)$ arsenic and $(B)$ iron and manganese withdrawn from the EXP-2 shallow well after treatment with low $(0.37 \mathrm{mg} / \mathrm{L})$, moderate $(3.3$ $\mathrm{mg} / \mathrm{L})$, and high $(6.4 \mathrm{mg} / \mathrm{L})$ iron concentrations at $\mathrm{pH}$ values ranging from 5.3 to 5.6 during Phase 1, in-situ arsenic remediation experiments, Douglas County, Nevada, September 2006.

detection in the low-iron treatments. Manganese concentration in groundwater prior to treatment was approximately $17 \mu \mathrm{g} / \mathrm{L}$. However, manganese remained above the Nevada secondary drinking-water standard of $100 \mu \mathrm{g} / \mathrm{L}$ during most of the withdrawal period. The high iron and manganese concentrations likely resulted from the incomplete oxidation and precipitation of these elements with oxygen.

In the deep well, arsenic was not remediated to below $10 \mu \mathrm{g} / \mathrm{L}$, where iron and manganese concentrations were less than their respective secondary drinking-water standards (fig. 4). The high iron treatment $(5.0 \mathrm{mg} / \mathrm{L})$ did result in the
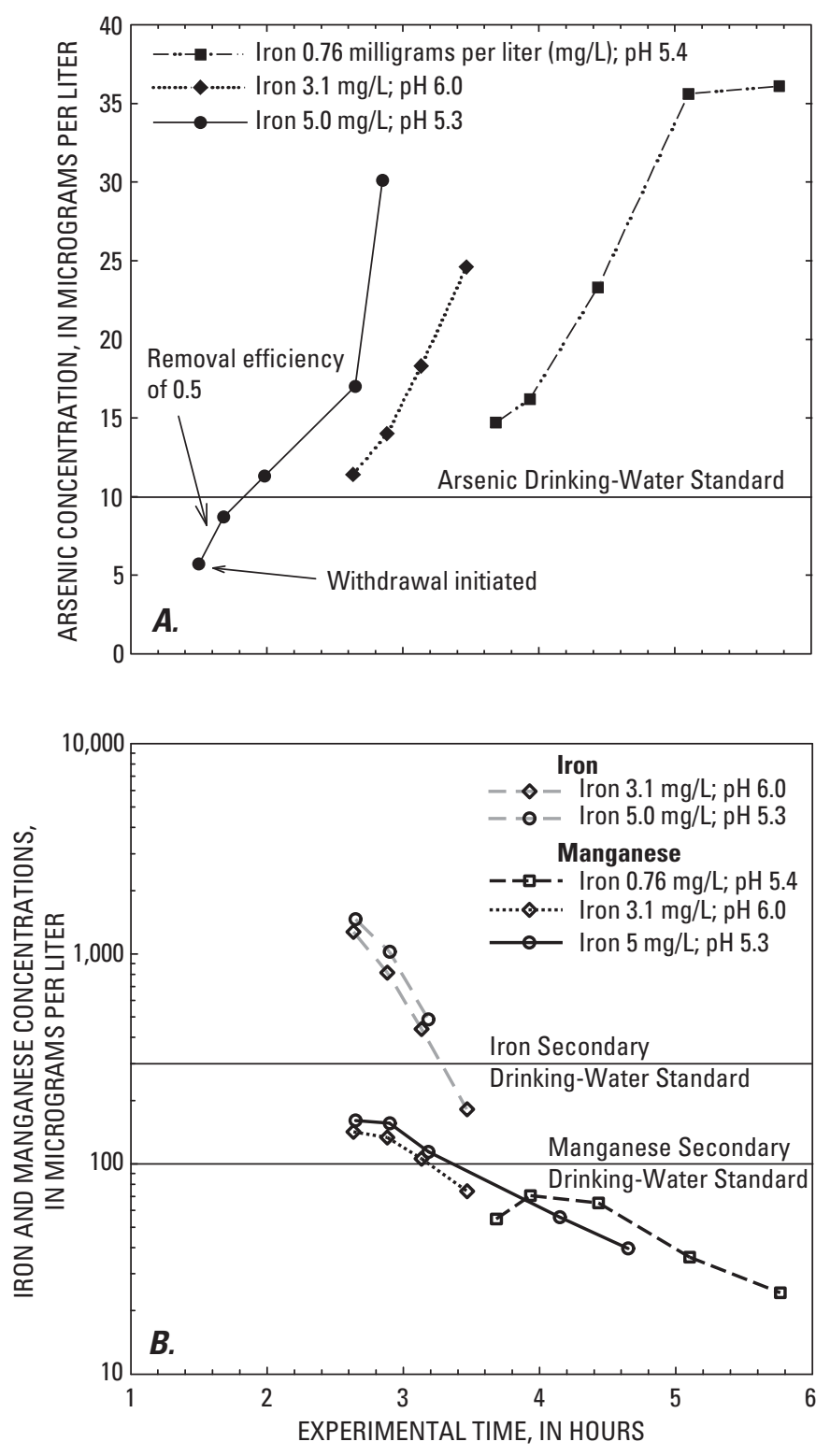

Figure 4. Concentrations of $(A)$ arsenic and $(B)$ iron and manganese withdrawn from the EXP-2 deep well after treatment with low $(0.76 \mathrm{mg} / \mathrm{L})$, moderate $(3.1$ $\mathrm{mg} / \mathrm{L})$, and high $(5.0 \mathrm{mg} / \mathrm{L})$ iron concentrations at $\mathrm{pH}$ values ranging from 5.3 to 6.0 , during Phase I, in-situ arsenic remediation experiments, Douglas County, Nevada, September 2006.

removal of arsenic to less than $10 \mu \mathrm{g} / \mathrm{L}$; however, the volume of remediated water recovered (183 gal) was only about one-half the volume of treated water injected. In the deep well, iron and manganese concentrations were above the secondary drinking-water standards during the initial period of the withdrawal period for the moderate $(3.1 \mathrm{mg} / \mathrm{L})$ and high $(4.9 \mathrm{mg} / \mathrm{L})$ iron treatments. Iron concentrations were below detection in the low-iron treatments in the deep aquifer experiments. Reducing arsenic to concentrations less than 
$10 \mu \mathrm{g} / \mathrm{L}$ was less effective in the deeper well because of the more reducing environment with depth. Dissolved oxygen and $\mathrm{pH}$ changed rapidly during early withdrawal, with dissolved oxygen being consumed to below detection. The dissolved oxygen likely was reacting with iron in the aquifer materials, which is consistent with the greenish gray color of the deeper sediments (Welch and others, 2008).

The experiments were limited by the relatively small volumes of treated water that were injected, generally about $300-400$ gal. Assuming a porosity of about 30 percent for aquifer sediments and uniform hydraulic properties, these volumes penetrated the aquifer to a radial distance of less than $0.33 \mathrm{ft}$ around the $20-\mathrm{ft}$ screened interval of the wells (Welch and others, 2008). It is hypothesized that repeated cycles of injection and withdrawal could lower the high concentrations of iron in withdrawn water if ferrous iron adsorbed onto newly formed iron oxide.

\section{Phase II Laboratory Column Experiments}

A core of aquifer material from the As-2 well was obtained from $310-315 \mathrm{ft}$ below land surface. The core material was processed under a nitrogen-gas atmosphere to prevent changes in the redox condition of the aquifer material during column preparation. Under the inert nitrogen-gas atmosphere, aquifer material was extracted from the $310-\mathrm{ft}$ end of the core and packed into an oxygen impermeable Plexiglas ${ }^{\circledR}$ column, $0.98 \mathrm{ft}$ long with a $0.083 \mathrm{ft}$ inside diameter (volume of $0.005 \mathrm{ft}^{3}$ ). Each end of the column contained filter disks to prevent the escape of fines and capped to prevent the entry of air. The column containing wet aquifer material was removed from the nitrogen-gas atmosphere and weighed prior to starting the experiment. After the experiment was completed the aquifer material was extracted and dried and column porosity calculated (41 percent). A pore volume is the amount of liquid that resides in the void (pore) space within a given volume of porous material. In these laboratory experiments, the pore volume $(63 \mathrm{~mL})$ was the amount of fluid contained in the column of aquifer material at one time.

During the laboratory experiments, water was pumped from the bottom of the column to the top. In this report, water pumped into the column is called source water, and water flowing out of the column is called leachate. The column used in the experiment was a closed system. Because the source water used in the column experiment was saturated with oxygen the column experiment was under ambient atmospheric conditions. Leachate was collected from the column in polypropylene bottles modified to allow sample collection under a nitrogen-gas atmosphere. The column was wrapped with aluminum foil to prevent any photocatalyzed reactions. At the end of each day, the column was sealed to prevent oxygen diffusion into the sediment.
Two different source waters were used during the experiment. Source-water 1 was aerated but otherwise untreated, simulating pre-aerated water used during Phase II field experiments where groundwater was pumped to the surface, oxygenated, and then injected back into the aquifer. The composition of source-water 1 (table 2) was similar to that reported by Welch and others (2008). Source-water 1 was not treated with iron or acid; dissolved-oxygen was about $6 \mathrm{mg} / \mathrm{L}$, and $\mathrm{pH}$ was 8.62. About five pore volumes of this source water were pumped through the column at a rate of about 1.5 pore volumes per day.

Following the pumping of the 5 pore-volumes of sourcewater 1 through the column, the source water was changed to source-water 2. The composition of source-water 2 was similar to that expected following aeration, $\mathrm{pH}$ adjustment, and iron addition (table 2). Ferrous iron was about $7 \mathrm{mg} / \mathrm{L}$, arsenic was added as arsenate, $\mathrm{As}(\mathrm{V}), \mathrm{pH}$ was about 5.5 , and dissolved oxygen was about $6 \mathrm{mg} / \mathrm{L}$. Ferrous iron in sourcewater 2 was stable only for about 10 hours before measurable oxidation began; therefore, source-water 2 was prepared daily. Initial flow rates were adjusted to elute about 1-1.5 pore volumes during a 5-7 hour period. Eventually, flow rates gradually were increased until about 3-6 pore volumes per day of leachate were collected. The experiment ran for 147 days and at the end of each day the column was sealed to prevent oxygen diffusion into the sediment.

Table 2. Source-water composition for laboratory column experiments using core material from wells drilled as part of the Phase II, in-situ arsenic remediation study, Douglas County, Nevada.

[Abbreviations: $\mathrm{O}_{2}$, diatomic oxygen; $\mathrm{mg} / \mathrm{L}$, milligram per liter; $\mu \mathrm{g} / \mathrm{L}$, microgram per liter; $\mathrm{SiO}_{2}$, silica dioxide; $\sim$, approximately]

\begin{tabular}{lcc}
\hline \multicolumn{1}{c}{$\begin{array}{c}\text { Constituent and } \\
\text { unit of measure }\end{array}$} & Source-water 1 & Source-water 2 \\
\hline $\begin{array}{l}\text { Dissolved oxygen, } \\
\text { mg/L as } \mathrm{O}_{2}\end{array}$ & $\sim 6$ & $\sim 6$ \\
$\mathrm{pH}$, standard units & 8.62 & $\sim 5.5$ \\
Calcium, $\mathrm{mg} / \mathrm{L}$ & 16.0 & 16.0 \\
Sodium, $\mathrm{mg} / \mathrm{L}$ & 47.0 & 47.0 \\
Potassium, $\mathrm{mg} / \mathrm{L}$ & 0.9 & .9 \\
Silica, $\mathrm{mg} / \mathrm{L}$ as $\mathrm{SiO}{ }_{2}$ & $\sim 42$ & $\sim 42$ \\
Sulfate, $\mathrm{mg} / \mathrm{L}$ & 38.4 & 38.4 \\
Chloride, $\mathrm{mg} / \mathrm{L}$ & $\sim 50$ & 1 \\
Bicarbonate, $\mathrm{mg} / \mathrm{L}$ & 9.2 & 22.3 \\
Arsenite, $\mu \mathrm{g} / \mathrm{L}$ & 30 & 0 \\
Arsenate, $\mu \mathrm{g} / \mathrm{L}$ & 0 & $\sim 70$ \\
Ferrous iron, $\mathrm{mg} / \mathrm{L}$ & 0 & \\
\hline${ }^{1}$ Chloride concentrations were calculated from the amount of hydrochloric \\
acid needed to adjust $\mathrm{pH}$ to 8.62 and 5.5.
\end{tabular}




\section{Laboratory Column Results}

Arsenic concentrations in leachate for the first five pore volumes were about $30 \mu \mathrm{g} / \mathrm{L}$ (fig. 5). Source-water 1 contained $30 \mu \mathrm{g} / \mathrm{L}$ arsenite; however, the leachate contained about 7-8 $\mu \mathrm{g} / \mathrm{L}$ arsenite and $22-24 \mu \mathrm{g} / \mathrm{L}$ arsenate. Arsenite is relatively stable in the presence of oxygen (Eary, 1987; Lowry and Lowry, 2002); therefore, something in the sediment, possibly manganese oxide minerals, likely catalyzed the oxidation of arsenite (Moore and others, 1990). The high concentrations of arsenic in the first 5 pore volumes of leachate indicates a lack of coprecipitation and sorption, probably because of the high $\mathrm{pH}$, low iron, and lack of adsorption sites.

After changing to source-water 2 (table 2), arsenic concentrations in leachate decreased rapidly at first and then more slowly (fig. 5). Arsenic was reduced to below drinkingwater standards after about 30 pore volumes, when the concentration apparently reached equilibrium ranging from about $6-8 \mu \mathrm{g} / \mathrm{L}$ for the next 300 pore volumes (fig. 5). Most arsenic was in the oxidized form, $\mathrm{As}(\mathrm{V})$, indicating no change in arsenic speciation during the experiment. The decrease in arsenic concentrations likely is a result of coprecipitation with the fresh hydrous ferric oxide (HFO) near the influent end of the column. After 150 pore volumes, Fe(II) was excluded from the source water, arsenic concentrations slowly began to increase because of the discontinued coprecipitation with ferric oxide and the lack of available sorption sites. At pore volume 200, arsenic concentration in the leachate reached $20 \mu \mathrm{g} / \mathrm{L}$. At this point Fe(II) was then added back to the source water and arsenic concentrations decreased. The laboratory column results indicate that arsenic concentrations can be decreased to values below the drinking-water standard by aeration and the addition of ferrous iron and acid.

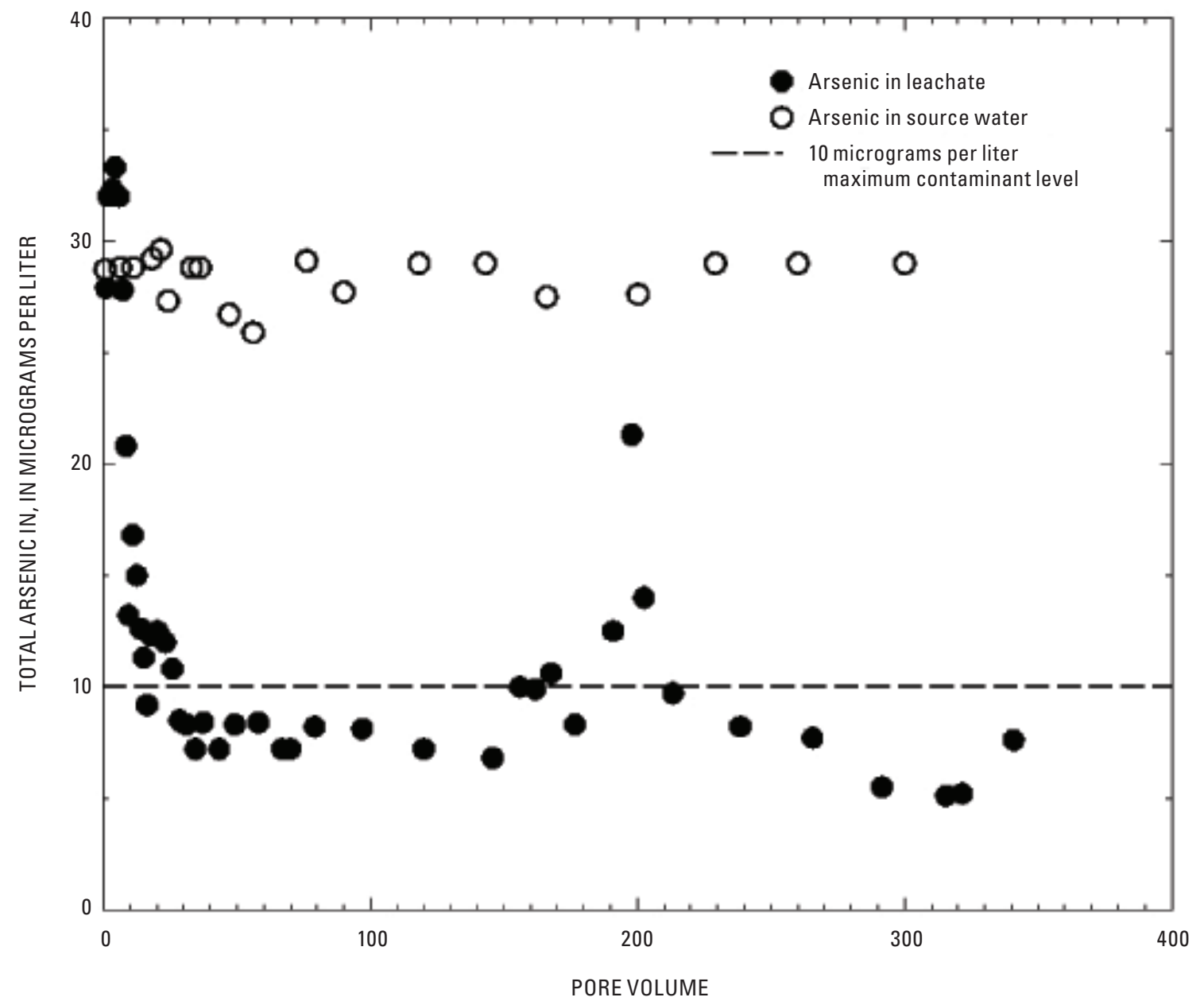

Figure 5. Arsenic concentrations in leachate and source water from column experiments, Douglas County, Nevada. 
The $\mathrm{pH}$ of source-water 1 used in the first five pore volumes was 8.62, similar to the groundwater at the south end of the Minden-Tahoe Airport, Douglas County, Nevada. The $\mathrm{pH}$ of the source water was then adjusted to about 5.5 with hydrochloric acid. After adjustment, the $\mathrm{pH}$ of the first pore volume of leachate was 8.31 then gradually increased to values of about 9.5 (fig. 6). The secondary drinking-water standard for $\mathrm{pH}$ ranges from 6.5 to 8.5 (U.S. Environmental Protection Agency, 2008); therefore, $\mathrm{pH}$ changes during in-situ treatment should be monitored. However, this secondary standard was exceeded before the treatment process (pre-treatment $\mathrm{pH}$ ranging from 8.1 to 8.9 ). One possible explanation for the increase in $\mathrm{pH}$ is dissolution of carbonate minerals. The narrow inlet and outlet openings of the column and the close packing of sediment grains in the column prevents rapid degassing of carbon dioxide $\left(\mathrm{CO}_{2}\right)$ and could have resulted in hydrolysis to carbonic acid $\left(\mathrm{H}_{2} \mathrm{CO}_{3}\right)$, causing an increase in $\mathrm{pH}$. This set of reactions was simulated using the geochemical modeling program PHREEQC

(Parkurst and Appelo, 1999). Sufficient calcium carbonate was allowed to dissolve to obtain an aqueous bicarbonate concentration similar to that measured in leachate, about $23 \mathrm{mg} / \mathrm{L}$ as bicarbonate. This reaction resulted in a $\mathrm{pH}$ of 9.5, and a partial pressure of carbon dioxide $\left(\mathrm{pCO}_{2}\right)$ of $10^{-5} \mathrm{~atm}$, compared to atmospheric $\mathrm{pCO}_{2}$ of $10^{-3.5} \mathrm{~atm}$. To increase the rate of dissolution of carbonate phases, source-water $\mathrm{pH}$ was decreased to about 5.2 at pore volume 100. Measured $\mathrm{pH}$ gradually decreased to 7.8 after about 340 pore volumes, likely a result of a decrease in carbonate minerals (ig. 6 ).

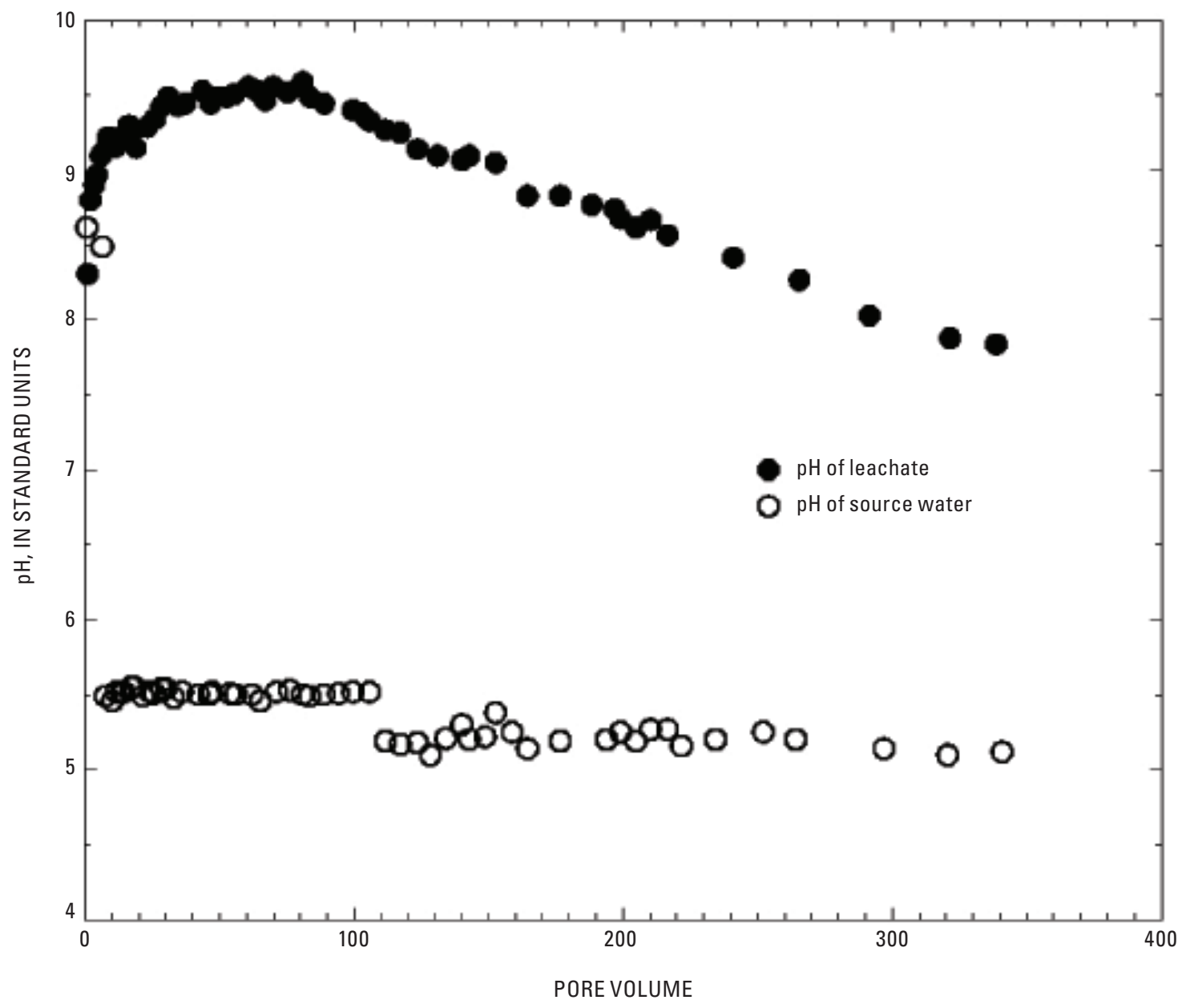

Figure 6. $\mathrm{pH}$ of leachate from column experiments, Douglas County, Nevada. 
PHREEQC simulations indicated that the solubility of hydrous ferric oxide at the highest $\mathrm{pH}$ measured in leachate, 9.5 , would be $5 \mu \mathrm{g} / \mathrm{L}$ as iron. Although, ferrous-iron concentration in source-water 2 was about $7 \mathrm{mg} / \mathrm{L}$, no iron was detected in the leachate for the 340 pore volume laboratory experiment. Visual inspection of the column showed that a front of reddish brown ferric oxide moved through the column. A decrease in flow rate was not evident as a result of iron oxide precipitation, which is in agreement with field observations during in-situ remediation efforts elsewhere (Rott and Friedle, 1999; Mettler and others, 2001). Manganese was not added to the source water; however, an initial manganese concentration of $134 \mu \mathrm{g} / \mathrm{L}$ occurred in the first pore volume (fig. 7). Manganese concentration rapidly decreased to about $1 \mu \mathrm{g} / \mathrm{L}$ after 18 pore volumes and remained between 1 and 2 $\mu \mathrm{g} / \mathrm{L}$ for the remainder of the experiment. Manganese phases were not determined in core material analyzed for mineralogy
(John McCormick, Nevada Bureau of Mines, University of Nevada, Reno, written commun., May 2008) suggesting that, if present, manganese oxides may be heterogeneously dispersed within the aquifer sediments. These results suggest limited dissolution of a manganese solid phase or desorption of manganese from aquifer materials under these experimental conditions.

\section{Phase II Field Experiment Design}

Phase II experiments were designed to refine methods of arsenic remediation in the deeper part of the aquifer where arsenite is the predominant arsenic species and reducing conditions prevail. The EXP-2 wells are sufficiently close $(1,600 \mathrm{ft})$ to the SAP\#1 well to provide similar hydrologic and geochemical conditions, yet sufficiently distant to avoid affecting water quality in the production well.

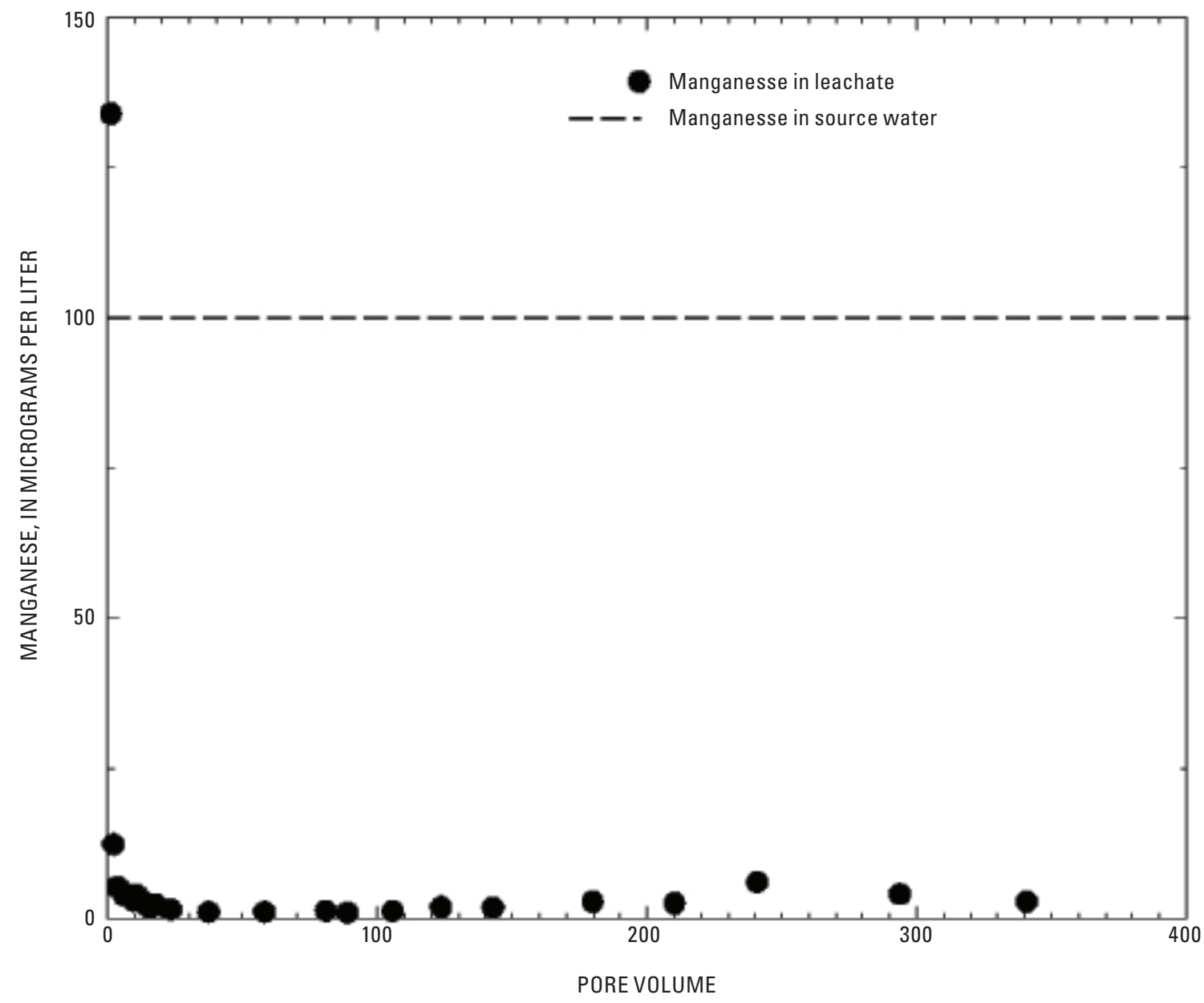

Figure 7. Manganese concentrations in leachate from column experiments, Douglas County, Nevada. 
Work for Phase II began in November 2007 and included the drilling of two wells in the deep aquifer near the EXP-2 wells, laboratory experiments using aquifer material obtained during drilling, and field experiments using the EXP-2 deep well and the two new wells. These wells were drilled to a depth of about $345 \mathrm{ft}$ and screened from 305 to $325 \mathrm{ft}$, similar to the construction of the existing EXP-2 deep well. A 6-in. diameter well (As-6) was drilled $15 \mathrm{ft}$ from the EXP-2 deep well and a 2-in. diameter well (As-2) was drilled $10 \mathrm{ft}$ from the 6-in. well and $15 \mathrm{ft}$ from the EXP-2 deep well (figs. $\underline{1 B}$ and $\underline{8})$. Assuming a radius of influence around the As-6 well of $13 \mathrm{ft}$, an area of approximately $530 \mathrm{ft}^{2}$ theoretically would be affected during the in-situ experiments. Assuming a porosity of 10-30 percent and a 20-ft aquifer thickness (equal to the screened interval of the wells), 1 pore volume could range from approximately 7,900 to 23,800 gal (more than approximately $10,600 \mathrm{ft}^{3}$ of aquifer volume). During the initial Phase II experiment, water was withdrawn, by air-lift, from the As- 6 well and injected into the As-2 and EXP-2 deep wells to create cross-flow among them (fig. 8A). In a second Phase II experiment, water was withdrawn from the As-2 and EXP-2 deep wells and injected into the As-6 well (fig. 8B). Airlifting was used to oxygenate water during withdrawal. Such experiments allowed larger volumes of groundwater to be treated than the Phase I injection and withdrawal experiments, more closely simulating actual conditions at a functioning in-situ arsenic remediation site.

During Phase I experiments with the EXP-2 deep well, dissolved oxygen was consumed rapidly, resulting in the incomplete precipitation of iron oxide. To improve arsenic remediation and prevent this rapid consumption of dissolved oxygen, the aquifer was first oxidized by introducing dissolved oxygen into the system prior to treatment with iron and acid. Pre-aeration of the aquifer was achieved by air-lifting water from one well and injecting the oxygenated water into adjacent wells.

\section{First Phase II Field Experiment and Results}

Water was air-lifted from a depth of about $140 \mathrm{ft}$ in the As-6 well into a 250-gal settling tank elevated about $5 \mathrm{ft}$ above the ground which drained into a 75-gal stock tank. Water from the stock tank was pumped through three $2-\mathrm{ft}^{3}$ activatedcarbon filters prior to injection by gravity feed into the As-2 and EXP-2 deep wells. A sampling pump was placed in the As-6 well about $100 \mathrm{ft}$ below the level of air-lifting (As-6 Sampling Port, fig. $8 \mathrm{~A}$ ) to allow sampling of water unaffected by air-lifting and to detect breakthrough of injected water.
Beginning June 4, 2008, water was injected without treatment (pre-aeration) on four separate days prior to the initial Phase II experiment. Initial injection rates were 12-15 gal/min at the As-2 well and EXP-2 deep well, respectively. After about 1 hour of injection, however, water began to overflow from the wells, which indicated clogging, possibly caused by air entrained in the injected water. Air lifting of the injection wells after a day of injection was required to regain the initial injection rates of $12-15 \mathrm{gal} / \mathrm{min}$. Additionally, the carbon filters became clogged after 2-3 hours of operation requiring back flushing to maintain a total flow rate of about $20 \mathrm{gal} / \mathrm{min}$. Over the 4 days of air-lift and injection without treatment, the combined injection rate at both wells ranged from 5 to $25 \mathrm{gal} / \mathrm{min}$, and 13,400 gal (approximately 0.6-1.7 pore volumes) was injected. Oxygenated water was not detected at the As-6 well.

On June 23, 2008, injection of treated water began. Treatment proceeded in a step-wise fashion starting with (1) aeration by air lifting, (2) conversion of As(III) to As(V) using chlorination, (3) activated -charcoal filtration to remove free chlorine, (4) addition of acid to achieve a $\mathrm{pH}$ of approximately 5.5 , and, finally, (5) addition of iron to achieve a concentration of $7 \mathrm{mg} / \mathrm{L}$, in the injected water (fig. 8A, $\underline{B}$ ). Rates of reagent addition were adjusted until the target treatment concentrations were achieved (table 3 ). Combined injection rates ranged from 5 to $19 \mathrm{gal} / \mathrm{min}$ and a total volume of $5,740 \mathrm{gal}$ were injected (table 4).

Prior to injection of treated groundwater, $\mathrm{As}(\mathrm{V})$ composed 93 percent $(35.9 \mu \mathrm{g} / \mathrm{L})$ of the arsenic in treated groundwater (fig. 8A, between steps 3 and 4; table 5). These results indicate that the chlorination was effective in oxidizing As(III) to As(V). Arsenic concentrations in samples collected from the deep sampling port in the As-6 well were predominately As(III) indicating that oxidized conditions did not reach the well. Dissolved-oxygen concentrations ranged from 6.3 to $9.0 \mathrm{mg} / \mathrm{L}$ in groundwater airlifted from As-6, approximately 65-94 percent of saturation (fig. 8A, at step 1). Dissolved oxygen did not break through to the As- 6 well over the 9.5-hour experiment, and was always less than $1 \mathrm{mg} / \mathrm{L}$.

Although the target treatment $\mathrm{pH}$ (5.5) was achieved, acidic $\mathrm{pH}$ was not observed at the As-6 well (fig. 9A). Groundwater $\mathrm{pH}$ did not exceed the upper limit of the secondary drinking-water criterion of 8.5. Although alkalinity did decrease somewhat at the As-6 well, the differences among alkalinity measurements were not outside the analytical variability of 2.5 percent (fig. $9 B$ ). 
A. Experiment No. 1, June 23, 2008
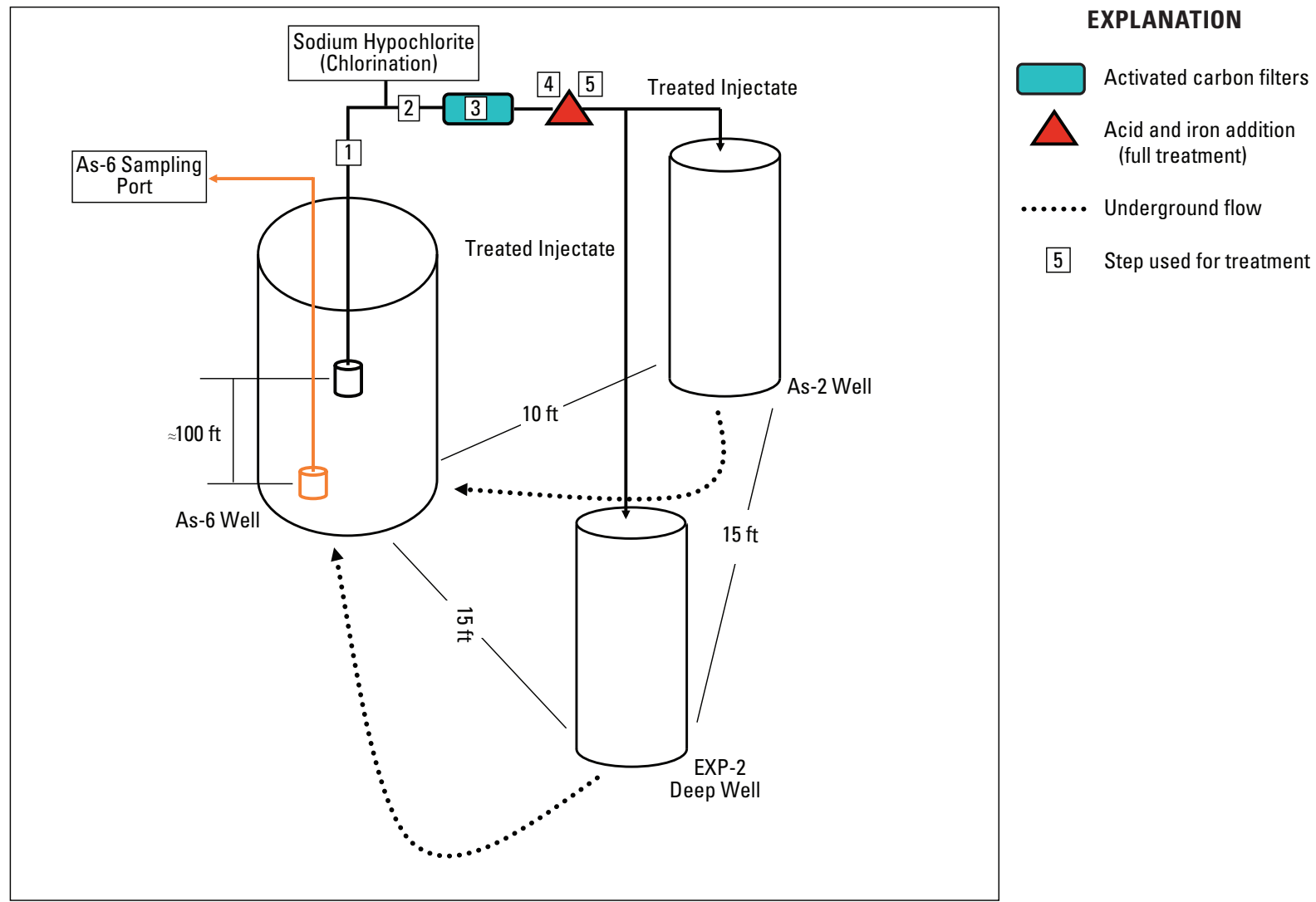

B. Experiment No. 2, October 16, 2008

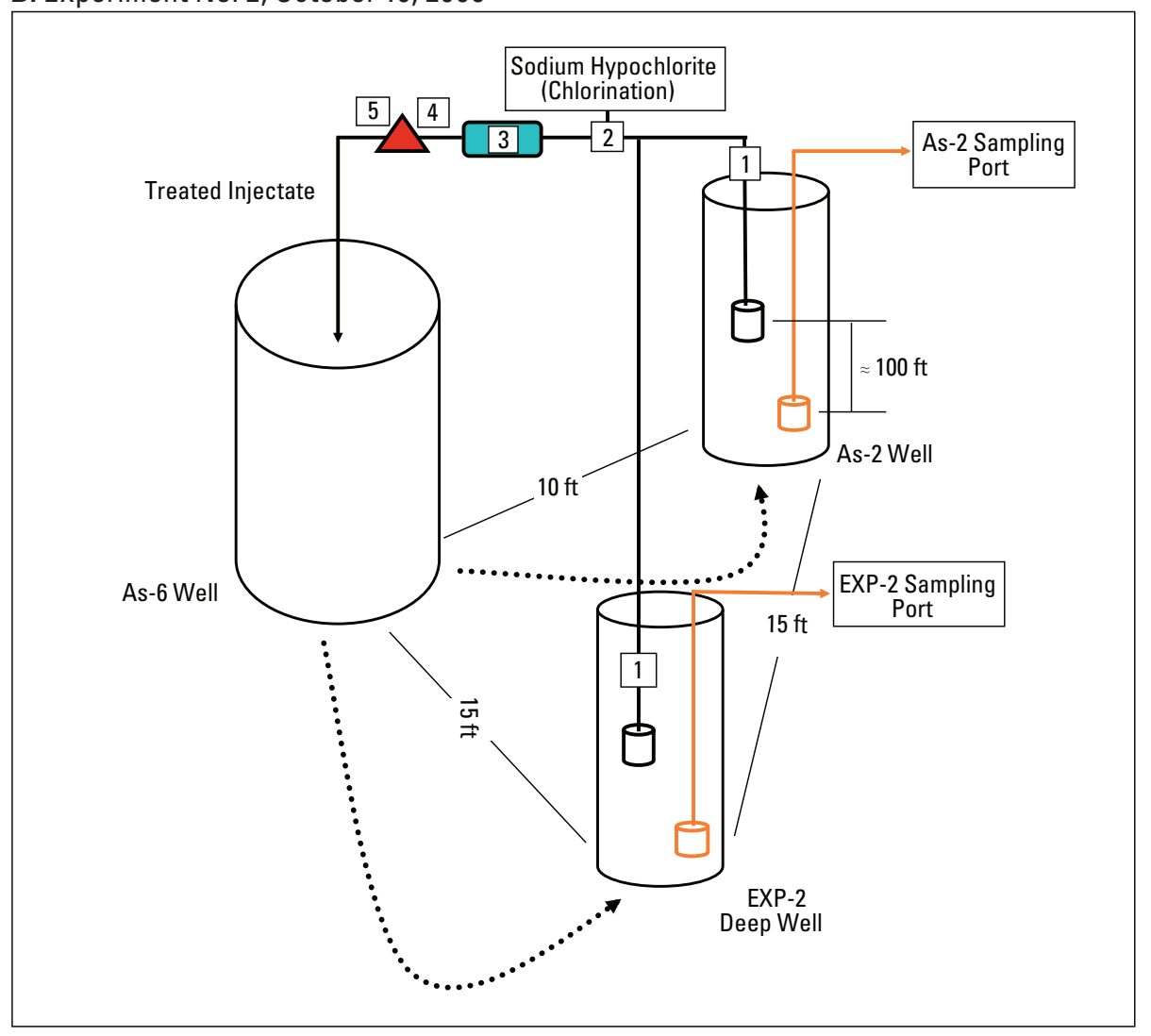

Figure 8. Schematic diagrams of treatment and sampling ports for Phase II in-situ arsenic remediation, Douglas County, Nevada. Numbers indicate steps in treatment. 
Table 3. Summary of treatment and concentrations of substances used during first Phase II field experiment No. 1, in-situ remediation of arsenic remediation, Douglas County, Nevada, June 23, 2008.

[Treatment: Sodium hypochlorite, used to oxidize arsenite to arsenate; Muriatic acid, $\mathrm{HCl}$ acid used to lower $\mathrm{pH}$ of groundwater to a target $\mathrm{pH}$ of 5.5; Ferrous chloride, source of iron to precipitate iron-oxide. Feed solution concentration: Concentrations determined based on information from manufacturer (ferrous chloride solution is 11 percent ferrous iron and specific gravity $1.28 \mathrm{gm} / \mathrm{mL}$; sodium hypochlorite solution is 12.5 percent $\mathrm{NaOCl}$, density $1.209 \mathrm{~g} / \mathrm{mL}$; muriatic acid is 31.4 percent $\mathrm{HCl}$ ). Density of muriatic acid determined during this study was $1.16 \mathrm{~g} / \mathrm{mL}$. Total amount of muriatic acid used during treatment expressed as muriatic acid. Total amount of treatment: Total amount of "treatment" used was adjusted for mass losses due to overflow of water from the injection well, EXP-2, during the experiment. Abbreviations: $\mathrm{mg} / \mathrm{mL}$, milligram per milliliter; $\mathrm{mL} / \mathrm{min}$, milliliter per minute; $\mathrm{mg} / \mathrm{L}$, milligram per liter; g, gram; g/mL, gram per milliliter; gal/min, gallon per minute. Symbols: $\mathrm{HCl}$, hydrochloric acid; $\mathrm{NaOCl}$, sodium hypochlorite, - , not available]

\begin{tabular}{lcccc}
\hline \multicolumn{1}{c}{ Treatment } & $\begin{array}{c}\text { Feed solution } \\
\text { concentration } \mathbf{( m g} / \mathbf{m L})\end{array}$ & Feed Rate (mL/min) & $\begin{array}{c}\text { In-stream } \\
\text { concentration (mg/L) }\end{array}$ & $\begin{array}{c}\text { Total amount of } \\
\text { treatment used }(\mathbf{g})\end{array}$ \\
\hline Sodium hypochlorite, as chloride & 1.71 & 68 & 12.19 & 337 \\
Muriatic acid & - & - & - & 27.474 \\
Ferrous chloride, as iron & 2.10 & - & 57 \\
\hline
\end{tabular}

\footnotetext{
${ }^{1}$ Based on a median flow rate of $14 \mathrm{gal} / \mathrm{min}$ (range of flow rates during treatment $12-15 \mathrm{gal} / \mathrm{min}$ ).

${ }^{2}$ Two samples collected after addition of ferrous chloride had unfiltered-iron concentrations of 6.8 and $8.2 \mathrm{mg} / \mathrm{L}$, respectively; the average concentration of $7.5 \mathrm{mg} / \mathrm{L}$ is reported in the table.

${ }^{3}$ Free chlorine from the sodium hypochlorite was removed, before the introduction of acid and iron, by passing the treated groundwater through activatedcarbon filters. These activated-carbon filters effectively removed free chlorine. Samples collected after flowing through the activated-carbon filters contained free chlorine concentrations less than $0.1 \mathrm{mg} / \mathrm{L}$ as determined in the field using a portable DR890 colorimeter $(\mathrm{HACH}, 2000)$.
}

Table 4. Volumes of groundwater through treatment system during first Phase II field experiment No. 1, in-situ arsenic remediation, Douglas County, Nevada, June 23, 2008.

[All values are in gallons. Treated groundwater injected: Volume of fully treated water (chlorination, acid, and iron) injected into the As-2 injection well was 690 gallons and into the EXP-2 well was 1,970 gallons (totaling 2,660 gallons); 1,100 gallons were treated only by chlorination and acid. Symbol: -, not applicable]

\begin{tabular}{lcccc}
\hline Well & $\begin{array}{c}\text { Groundwater } \\
\text { pumped }\end{array}$ & $\begin{array}{c}\text { Untreated } \\
\text { aerated } \\
\text { groundwater } \\
\text { injected }\end{array}$ & $\begin{array}{c}\text { Treated } \\
\text { groundwater } \\
\text { injected }\end{array}$ & $\begin{array}{c}\text { Total } \\
\text { groundwater } \\
\text { injected }\end{array}$ \\
\hline As-6 & 6,200 & - & - & - \\
As-2 & - & 380 & 1,140 & 1,520 \\
EXP-2 & - & 1,600 & 2,620 & 4,220 \\
Total & 6,200 & 1,980 & 3,760 & 5,740 \\
\hline
\end{tabular}

Samples collected during treatment with ferrous iron contained an average total-iron concentration of $7.5 \mathrm{mg} / \mathrm{L}$, indicating the target concentration for in-stream iron treatment was achieved. Full treatment (chlorination, acid, and iron addition) was maintained for approximately 2.5 hours, similar to Phase I experiments. Upon the termination of the injection experiment, and as long as 3 days after, iron concentrations measured in the deep EXP-2 injection well, remained below detection (less than $50 \mu \mathrm{g} / \mathrm{L}$ ). Manganese concentrations $(0.5-36.6 \mu \mathrm{g} / \mathrm{L})$ measured in this same well remained below the secondary drinking-water criterion of $100 \mu \mathrm{g} / \mathrm{L}$. These results indicate that enough oxygen was available to precipitate iron and manganese from solution. Pre-aeration of the aquifer prior to treatment was effective in preventing concentrations of iron and manganese from exceeding their respective secondary drinking-water criteria during this experiment. 
Table 5. Concentration of various arsenic species determined for samples collected during first Phase II field experiment No. 1, in-situ arsenic remediation, Douglas County, Nevada, June 23-24, 2008.

\begin{tabular}{|c|c|c|c|c|c|c|c|c|c|}
\hline \multirow{2}{*}{$\begin{array}{l}\text { Sample } \\
\text { collection }\end{array}$} & \multirow{2}{*}{$\begin{array}{c}\text { Site } \\
\text { identification } \\
\text { No. }\end{array}$} & \multirow[b]{2}{*}{ Date } & \multirow[b]{2}{*}{ Time } & \multicolumn{5}{|c|}{ USGS NWOL ( $\mu \mathrm{g} / \mathrm{L})$} & \multirow{2}{*}{$\begin{array}{l}\text { USGS GD } \\
\text { As ( } \mu \mathrm{g} / \mathrm{L})\end{array}$} \\
\hline & & & & $\mathrm{As}(\mathrm{V})$ & As(III) & DMA & MMA & $\begin{array}{c}\text { Sum of As } \\
\text { species }\end{array}$ & \\
\hline \multirow[t]{3}{*}{ As-6 (well) } & 385927119445605 & $06-23-08$ & 0940 & 4.0 & 31.2 & 0.71 & Е 0.26 & 36.2 & 34.9 \\
\hline & & 06-23-08 & 1400 & 5.7 & 30.1 & .65 & E. 23 & 36.7 & 35.8 \\
\hline & & 06-23-08 & 1600 & 7.1 & 30.2 & .67 & E. 22 & 38.2 & 36.7 \\
\hline \multirow{2}{*}{$\begin{array}{l}\text { Post-chlorination } \\
\text { (treatment stream) }\end{array}$} & nd & $06-23-08$ & 1130 & 17.5 & 9.9 & E. 33 & E. 12 & 27.8 & 27.1 \\
\hline & & $06-23-08$ & 1645 & 35.9 & E .23 & E.16 & E. 02 & 36.3 & 38.7 \\
\hline \multirow[t]{3}{*}{ EXP-2 (well) } & 385927119445601 & $06-23-08$ & 1755 & 22.7 & 6.6 & E. 27 & E. 09 & 29.7 & 29.5 \\
\hline & & 06-24-08 & 1000 & 8.7 & 6.6 & E. .05 & E. 25 & 15.6 & 15.0 \\
\hline & & $06-26-08$ & 0945 & nd & nd & nd & nd & nd & 26.9 \\
\hline
\end{tabular}

During pre-aeration and the June 23 Phase II in-situ remediation experiment, the injection capacity of the 2 -in. wells (EXP-2 and As-2 well) decreased over 4-5 hours and the wells overflowed. This decrease in injection capacity likely was caused by entrained air from treated water cascading into the injection wells. The total volume of water pumped from the As-6 well during the 9.5-hour experiment was 6,200 gal. About 1,980 gal of aerated water was injected into injection wells As-2 and EXP-2 deep, followed by about 3,760 gal of treated injectate, for a combined total of 5,740 gal (table 4). An estimated 460 gal overflowed from the injection wells. Given that one pore volume ranges from about 7,900 to 23,800 gal, the total volume of groundwater pumped from the As-6 well during the 9.5-hour experiment ranged from 0.3 to 0.8 pore volume. The estimated amount of treated water injected was equivalent to 0.2 to 0.5 pore volume.

During the initial Phase II, arsenic remediation was not apparent in water sampled from the As-6 well (ig. 10). Although the injected water had a $\mathrm{pH}$ of 5.5 , the $\mathrm{pH}$ of water in the As-6 well did not change over the course of the experiment (fig. 9A). Dissolved oxygen did not break through to the As-6 well during the 9.5-hour experiment, and was always less than $1 \mathrm{mg} / \mathrm{L}$. This lack of change in $\mathrm{pH}$ likely was a result of the small amount of groundwater treated (0.2-0.5 pore volume), the relatively high $\mathrm{pH}$ within the aquifer, and short treatment time.
At the conclusion of the first Phase II in-situ arsenic remediation experiment, samples were collected from the EXP-2 deep injection well. The EXP-2 deep well was selected for sampling because it received most of the injected water (4,200 gal) during the 9.5-hour experiment. Arsenic speciation data indicated that arsenic was primarily $\mathrm{As}(\mathrm{V})$ in the injectate (table 5). Arsenate was $15 \mu \mathrm{g} / \mathrm{L}$ in the EXP-2 deep injection well 1 day after the experiment, about one-half the initial concentration $(30 \mu \mathrm{g} / \mathrm{L})$. The iron probably precipitated near the site of injection, coprecipitating with arsenic. Arsenic concentrations within the EXP-2 deep well increased to about $27 \mu \mathrm{g} / \mathrm{L}$ within 3 days after treatment (table 5; fig. 10).

The lack of arsenic remediation in the As- 6 well likely was a result of the small amount of iron used in this experiment relative to the amount of water requiring treatment. The reduction in arsenic concentration in the sample collected from the EXP-2 deep injection well, 1 day after the experiment suggests that longer reaction times could result in greater arsenic remediation.

\section{Second Phase II Field Experiment and Results}

The problems with clogged injection wells and activatedcarbon filters influenced the design of the second Phase II field experiment. In an attempt to alleviate the clogging of the well, the experimental plan was altered such that water 

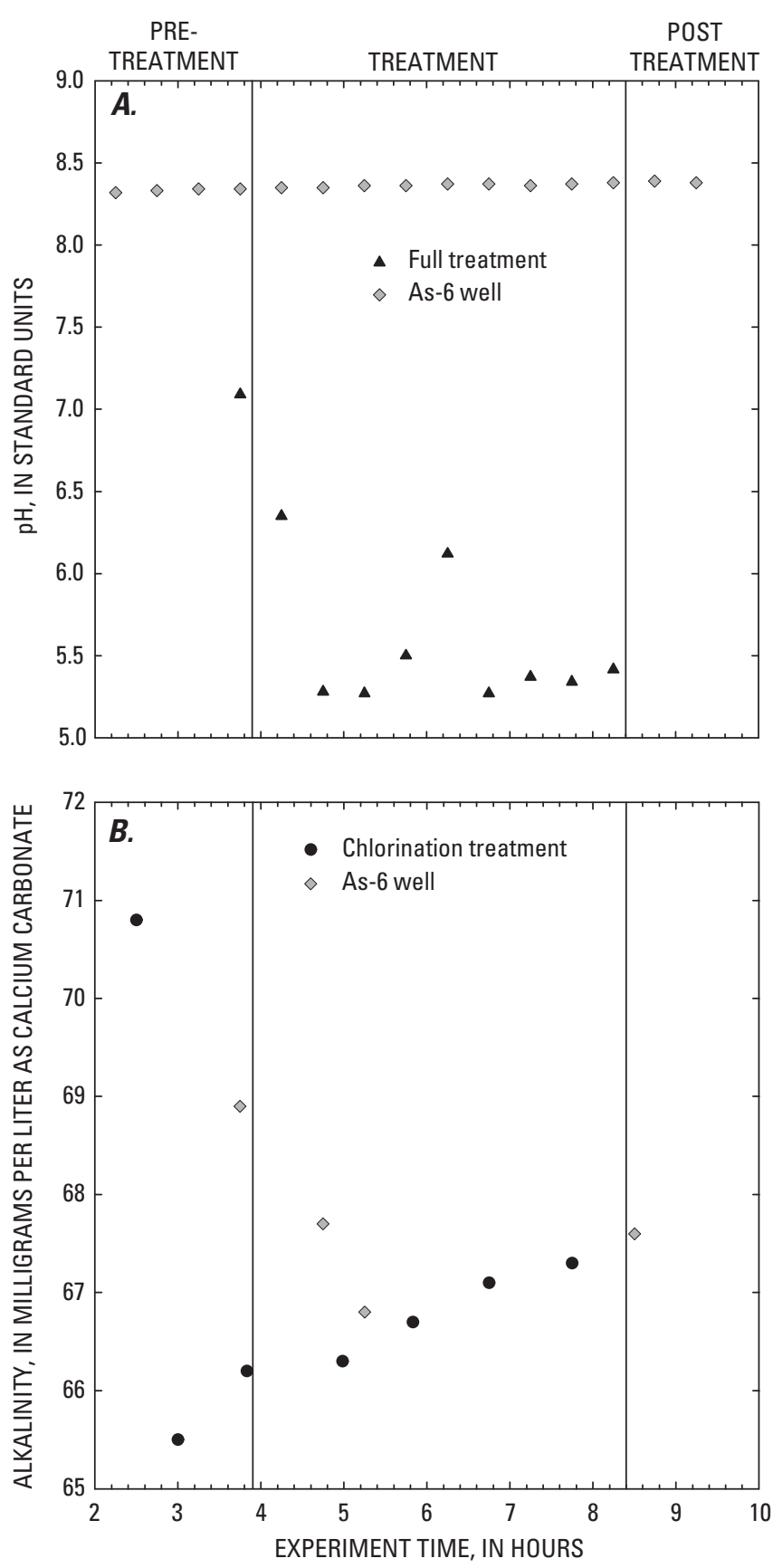

Figure 9. Measured $(A) \mathrm{pH}$ and $(B)$ alkalinity during Phase II experiment No. 1, in-situ arsenic remediation, Douglas County, Nevada, June 23, 2008. Full treatment is chlorination and addition of ferrous iron and acid.

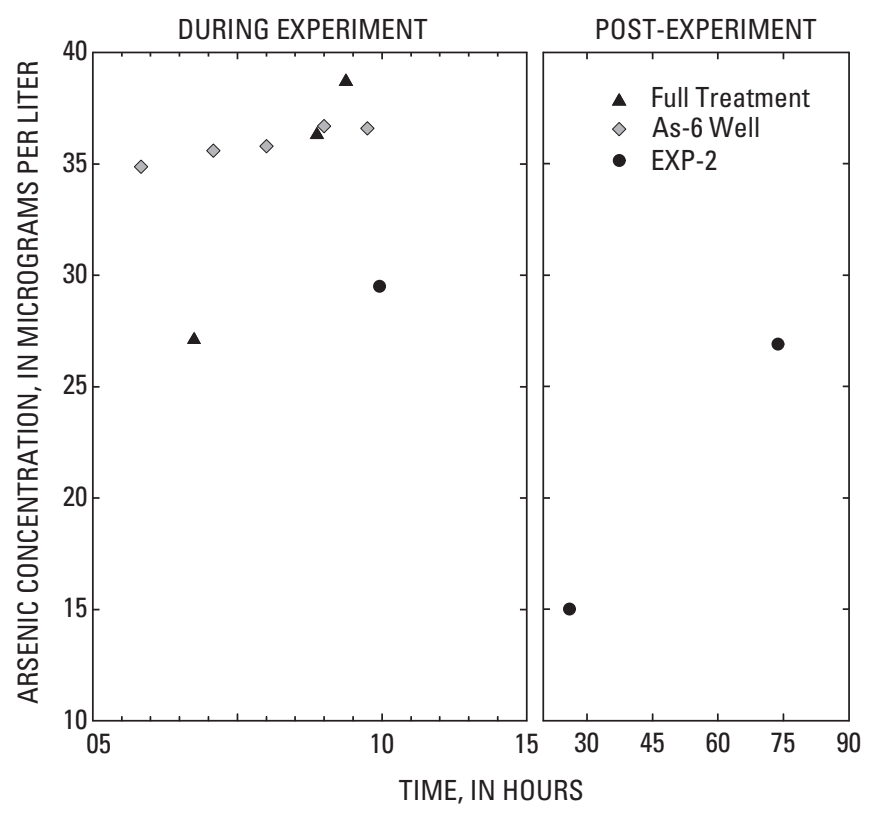

Figure 10. Remediation of arsenic during and after Phase II experiment No. 1, in-situ arsenic remediation, Douglas County, Nevada, June 23-26, 2008.

was air-lifted from a depth of $120 \mathrm{ft}$ in the As-2 and EXP-2 deep wells and injected into the larger diameter As- 6 well (fig. $8 B$ ). With the exception of the reversal of flow direction, experimental set up and treatment were the same as for the first Phase II experiment, and sampling pumps were placed about $80 \mathrm{ft}$ below the point of air-lift (fig. $8 B$ ) in the As-2 well and EXP-2 deep well to detect breakthrough of injected water. Additionally, plans were made to continue air-lifting, treating, and injecting continuously for several days to achieve the treatment of approximately 30 pore volumes $(237,000$ 714,000 gal), estimated by the laboratory column experiments as necessary to remove arsenic to concentrations less than the drinking-water standard.

Preparation for the second experiment began in October 2008 with air-lift testing of the As-2 well and EXP-2 deep well, and injection without treatment into the As-6 well. Initial air-lift rates were about 9 and $11 \mathrm{gal} / \mathrm{min}$ from the EXP-2 deep well and As-2 well, respectively. The maximum pumping rate obtained through the activated-carbon filters was limited to $12-13 \mathrm{gal} / \mathrm{min}$, thereby limiting the injection rate into the As-6 well, with $7-8 \mathrm{gal} / \mathrm{min}$ being lost to waste.

When determining the rates of sodium hypochlorite, acid, and iron deliveries, the rate of flow through the activatedcarbon filters began to decrease to less than $5 \mathrm{gal} / \mathrm{min}$. The decrease in flow through the filters likely was caused by clogging with entrained air. After backflushing the filters, the original injection rate of about $13 \mathrm{gal} / \mathrm{min}$ was restored; 
however, backflushing eventually became necessary every 35-minutes (fig. 11A). After about 5 hours of air-lift and injection, air-lift rates from the EXP-2 deep and As-2 wells decreased to 7 and $9 \mathrm{gal} / \mathrm{min}$, respectively (fig. $11 \mathrm{~B}$ ). The reason for the decrease in air-lift rates is not certain, but it may have been caused by the greater rate of air-lift than injection.
Additionally, the rate of groundwater flow between the wells may have been less than the air-lift and injection rates, causing a decline in water level in the pumped wells. Lowering the depth of air-lift and sampling pumps in the EXP-2 deep well and As- 2 well temporarily alleviated the decreasing air-lift rates, but available sampling pumps were limited to a depth of
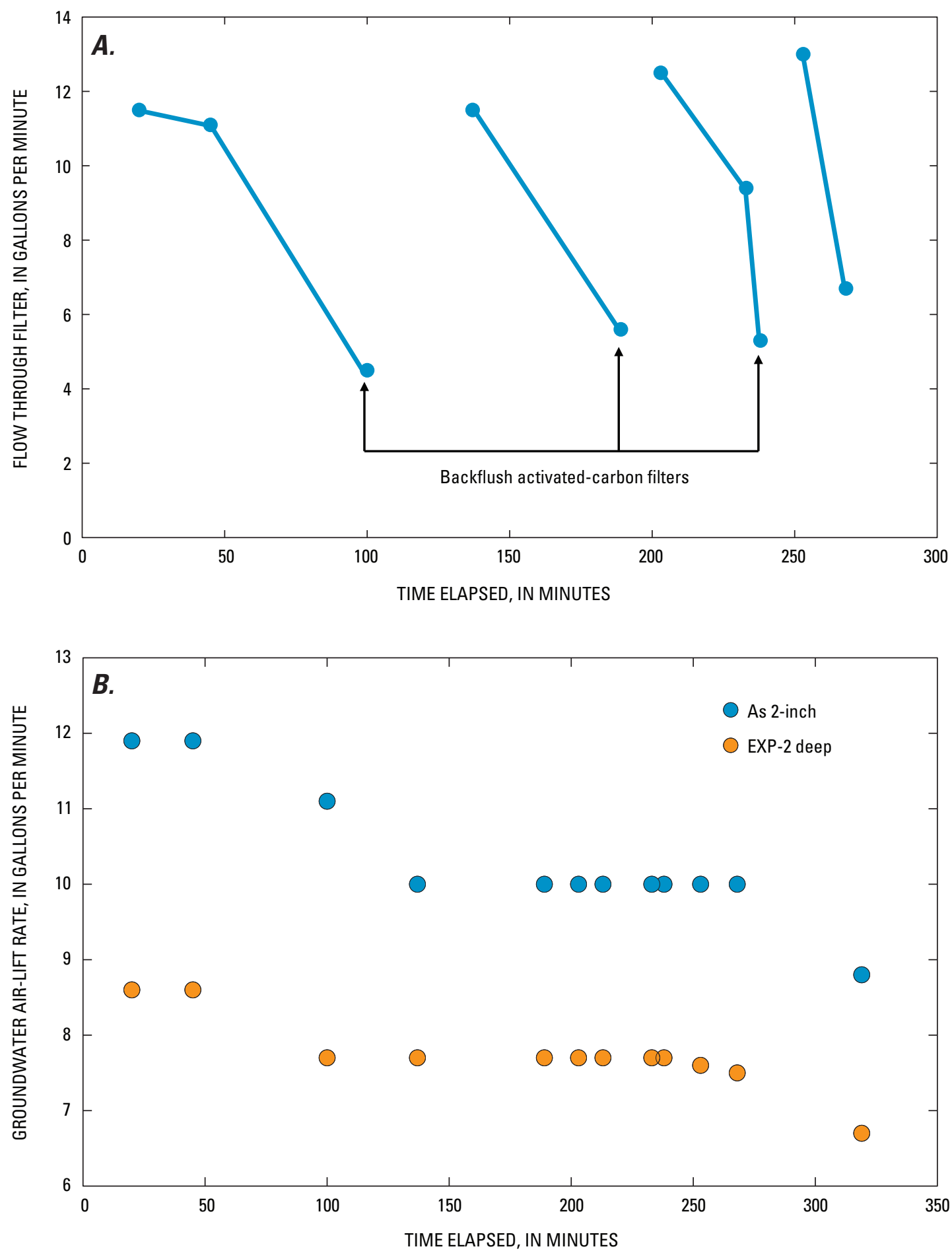

Figure 11. Groundwater flow through $(A)$ activated carbon filters and $(B)$ air-lift rates during the second Phase II field experiment, in-situ arsenic remediation, Douglas County, Nevada, October 16, 2008. 
$200 \mathrm{ft}$. The decreasing air-lift rates, and the constantly varying rates of pumping through the activated-carbon filters, did not allow maintenance of the target concentrations for the addition of chlorine, acid, and iron. Continuous air-lift, treatment, and injection for several days would not be possible using this small-scale design and so the experiment was stopped.

\section{Discussion of Phase I and II Experiments}

Problems observed during the Phase II experiments generally were due to system engineering and may not be insurmountable obstacles to successful in-situ arsenic remediation. Results of the Phase I and laboratory column experiments suggest that the remediation of arsenic to less than the drinking-water standard can be attained. The problem of well clogging during injection might be solved by the use of larger vented settling tanks that would allow holding water for longer periods than is possible with the 250-gal tank used in the Phase II experiments. The large, vented tanks would allow for the escape of entrained gas and provide injection water less likely to clog the well and filter. Installation of multiple larger diameter injection wells with longer screened intervals would allow greater volumes of water to be pumped, treated, and re-injected, and would allow for alternating injection among wells, a method already applied for systems using in-situ remediation (Mettler and others, 2001). An injection method other than gravity feed may improve the ability of the aquifer surrounding the injection well to receive treated water. The decrease in air-lift rates may be alleviated by the use of longer and more easily lowered air-lift lines and sampling pumps with longer intakes, or by air-lifting from alternate wells. Similarly, clogging of carbon filters could be overcome by switching to large-capacity filters or by alternating between filters while clogged filters are backflushed, or both.

Switching injection or air-lifting among wells and filters may alleviate many problems; however, the maintenance of such a system may be substantial. Problems may occur when using a production well and separate injection wells because wells may have different producing zones (Rott and Friedle, 1999). Rott and Meyerhoff (1994) point out the advantage of using the same well for pumping, treatment, and injection because treated water enters the same zones producing water from the well. They note that two working remediation wells in an area can be used to provide a constant supply of potable drinking water by switching remediation and production between the two wells. A similar method is used at the La Neuveville Site, a municipal supply well, in Switzerland (Mettler and others, 2001). If the problems of clogging can be overcome and relatively constant rates of injection obtained, treatment chemicals can be added at constant rates to achieve target concentrations, reducing the maintenance required for an operational remediation system.

\section{Summary and Conclusions}

Arsenic is one of the most common contaminants in groundwater in the western United States. Because of the lowering of the arsenic drinking-water standard from 50 to $10 \mu \mathrm{g} / \mathrm{L}$, water purveyors in many areas within the United States have been searching for new cost-effective methods to remove arsenic in order to comply with the new standard. Conventional arsenic remediation strategies primarily involve above-ground treatment that includes costs of building large treatment plants and costs associated with the disposal of sludge material. Two primary advantages of using in-situ remediation are the relatively small-scale facilities needed and the elimination of sludge-related disposal issues and costs.

Arsenic concentrations in groundwater in Douglas County, Nevada, range from 1 to $85 \mu \mathrm{g} / \mathrm{L}$. A two-phase study was implemented in 2005 and 2008 to address the possibility of using in-situ arsenic remediation. The first phase (Phase I) examined the feasibility of in-situ remediation, using one well for treatment and withdrawal at the south end of the MindenTahoe Airport. The second phase (Phase II) incorporated the results of Phase I and evaluated the effectiveness of in-situ remediation using a three-well system for injection and withdrawal to create cross flow between the wells, a method more applicable to full-scale implementation.

Phase I results indicate that arsenic concentrations in groundwater in Douglas County, Nevada, can be lowered to less than $10 \mu \mathrm{g} / \mathrm{L}$ using chlorination, aeration, iron, and $\mathrm{pH}$ adjustment. During Phase I, treated groundwater from the deep aquifer was injected into the more oxidizing shallow aquifer and reducing deep aquifer environments. Arsenic concentrations decreased to less than $10 \mu \mathrm{g} / \mathrm{L}$ from the shallow and deep aquifer when moderate to high iron (3-6 mg/L) treatments and $\mathrm{pH}$ adjustments to less than 6 were used. The primary arsenic species in the shallow aquifer was arsenate, $\mathrm{As}(\mathrm{V})$, for which the remediation of arsenic was more effective. Recovery of remediated groundwater originating from the shallow aquifer showed removal efficiencies ranging from 0 , using low iron treatments, to 1.9 , when treating at 6 $\mathrm{mg} / \mathrm{L}$ iron at a $\mathrm{pH}$ of 5.3. Although arsenic from groundwater originating from the deep aquifer was remediated, the removal efficiency was only about 0.5 . Deep groundwater was remediated only when treated at $5 \mathrm{mg} / \mathrm{L}$ iron at a $\mathrm{pH}$ of 5.3 . The primary arsenic species within the deep aquifer is arsenite, the reduced form of arsenic. Additionally, dissolved oxygen introduced into the system during the deep aquifer remediation experiments was consumed at a more rapid rate than during the shallow aquifer remediation experiments. In shallow and deep experiments, iron and manganese concentrations exceeded respective secondary drinking-water criteria, likely as a result of the incomplete precipitation of iron and manganese oxides. 
Phase II experiments involved the drilling of two additional wells, laboratory column experiments using aquifer material derived from the drilling of these new wells, and field tests. The new wells were installed sufficiently close (radial distances of 10-15 ft) to the well used during Phase I experiments to be hydraulically connected to each other yet far enough away from the production well so that productionwell operations would not be influenced. Laboratory column experiments simulated proposed treatment as elucidated from Phase I experiments. The proposed remediation strategy involved pre-aeration of groundwater, treatment with high iron concentration $(7 \mathrm{mg} / \mathrm{L})$, and adjustment of $\mathrm{pH}$ to approximately 5.5 . The laboratory results indicated that approximately 30 pore volumes of water would have to be treated in order to sustain the removal of arsenic to concentrations less than $10 \mu \mathrm{g} / \mathrm{L}$.

Extrapolation of the laboratory results to the field indicated that approximately 237,000-714,000 gallons of groundwater originating from the deep aquifer would require treatment to achieve this remediation goal. The first Phase II field experiment indicated that the chemistry-related aspects associated with the proposed treatment strategy would work provided that an adequate number of pore volumes were treated and that sufficient reaction time was allowed. During the experiment, 3,760 gallons of groundwater, approximately $0.2-0.5$ of 1 pore-volume (7,900-23,800 gallons), were treated. Although remediated groundwater was not observed at the well from which water was being withdrawn during the 9.5-hour experiment, 1 day after the conclusion of this first Phase II experiment, arsenic concentration decreased from 30 to $15 \mu \mathrm{g} / \mathrm{L}$ in water collected from one of the wells used for injection. Additionally, the primary arsenic species at the time of sampling was arsenate, indicating that during this 24-hour post-experiment period somewhat oxidizing conditions prevailed near this well. Arsenic concentrations increased to $27 \mu \mathrm{g} / \mathrm{L}, 3$ days after the conclusion of the experiment.

The first Phase II remediation experiment was terminated at 9.5 hours because of treated-groundwater overflow from the injection wells, which began at about 4.5 hours into the experiment. To avoid this overflow a second experiment was attempted. In this second Phase II field experiment, water was air lifted from each of the 2-in. diameter wells (previously used for injection) and injected into the 6-in. diameter well (previously used for withdrawal). Although the 6-in. diameter well did not overflow, over time the air-lift rate from each of the 2 -in. diameter wells decreased by 2 gallons per minute. Additionally, groundwater flow rates through the activatedcarbon filters decreased from 12-13 gallons per minute to less than 5 gallons per minute. Backflushing the activated-carbon filters restored groundwater flow rates through the filters temporarily; however, backflushing was becoming necessary more frequently. Because of these hydraulic-related obstacles the experiment was stopped.
The difficulties encountered during both Phase II experiments may be overcome if engineered properly and then in-situ arsenic remediation in reduced aquifers may be successful. Successful remediation of arsenic concentrations to less than drinking-water standards during Phase I and laboratory column experiments support this possibility. Solutions to some of the hydraulic complications encountered during the Phase II experiments may include (1) installation and use of large, vented settling tanks to permit a continuous exchange of air between the groundwater and atmosphere to allow the release of entrained gas bubbles resulting in injection water that is less likely to clog well screens and filters (2) installation of multiple large-diameter injection wells with screened intervals longer than $20 \mathrm{ft}$ to provide the option of alternating injection among wells and increasing well capacity, (3) using a method other than gravity-feed injection to reintroduce treated water back into the aquifer, and (4) alternating the use of large-capacity or multiple activatedcarbon filters, or both. If the issues associated with well screen and filter clogging can be overcome, the necessary chemical treatment (chlorination, and addition of iron and acid) can be automated thereby reducing the maintenance requirements necessary for a conventional large-scale remediation system. In aquifers where ambient arsenic is $\mathrm{As}(\mathrm{V})$, chlorination would not be necessary thereby eliminating the need for subsequent activated-carbon filtration. In such aquifers, treatment would require only the addition of iron, aeration, and lowering of $\mathrm{pH}$, further simplifying the in-situ treatment process.

\section{Acknowledgments}

The authors gratefully acknowledge the Carson Water Subconservancy District for funding this project; the Minden Tahoe Airport for allowing the experiments to be conducted on airport property; Douglas County for use of the production well and assistance; and James Wood, Carl Thodal, Timothy Rowe and Keith Halford, U.S. Geological Survey, for their participation in the field experiments and guidance.

\section{References Cited}

Anderson, M.A., Ferguson, J.F., and Gavis, Jerome, 1976, Arsenate adsorption on amorphous aluminum hydroxide: Journal of Colloid and Interface Science, v. 54, no. 3, p. 391-399.

Appelo, C.A.J., and deVet, W.W.J.M., 2003, Modeling in-situ iron removal from groundwater with trace elements such as As, in Welch, A.H., and Stollenwerk, K.G., eds., Arsenic in ground water-Geochemistry and occurrence: Boston, Mass., Kluwer Academic Publishers, p. 381-401. 
Appelo, C.A.J., Drijver, B., Hekkenberg, R., and De Jonge, M., 1999, Modeling in-situ iron removal from ground water: Ground Water, v. 37, no. 6, p. 811-817.

Brown, R.A., Leahy, M.C., and Pyrih, R.Z., 1998, In situ remediation of metals comes of age-Remediation/Summer 1998: John Wiley and Sons, Inc., p. 81-96.

Cadena, F., and Kirk, T.L., 1995, Arsenate precipitation using ferric iron in acidic conditions: New Mexico Water Resources Research Institute Technical Completion Report, $17 \mathrm{p}$.

Chiu, V.Q., and Hering, J.G., 2000, Arsenic adsorption and oxidation at manganite surfaces- -1 . Method for simultaneous determination of adsorbed and dissolved arsenic species: Environmental Science and Technology, v. 34 , no. 10 , p. 2029-2034.

De Vitre, Richard, Belzile, Nelson, and Tessier, Andre, 1991, Speciation and adsorption of arsenic on diagenetic iron oxyhydroxides: Limnology and Oceanography, v. 36, no. 7, p. $1480-1485$.

Drever, J.I., 1988, The geochemistry of natural waters: Englewood Cliffs, N.J.: Prentice Hall, 437 p.

Druhan, J.L., Conrad, M.E., Williams, K.H., N'Guessan, L., Long, P.E., and Hubbard, S.S., 2008, Sulfur isotopes as indicators of amended bacterial sulfate reduction processes influencing field scale uranium bioremediation: Environmental Science and Technology, v. 42, p. 78427849.

Eary, L.E., 1987, Rates of As(III) oxidation by dissolved oxygen at 25 and $90^{\circ} \mathrm{C}$ : Geological Society of America, Abstracts with Programs, v. 19, no. 7, p. 650.

ECO:LOGIC Engineering, 2003, South Airport exploratory well no. 2, construction and testing: Reno, Nev., Consulting Engineers memorandum report to Douglas County Community Development, Douglas County, Nevada, March 28, 2003, ECO:LOGIC Engineering, LLC, 18 p.

Edwards, Mark, 1994, Chemistry of arsenic removal during coagulation and Fe-Mn oxidation: Journal American Water Works Association, v. 9, p. 64-78.

Ferguson, J.F., and Gavis, Jerome, 1972, A review of the arsenic cycle in natural waters: Water Research, v. 6, p. $1259-1274$.

Ford, R., 2002, Rates of hydrous ferric oxide crystallization and the influence on coprecipitated arsenate: Environmental Science and Technology, v. 36, p. 2459-2463.
Frank, P.L., and Clifford, D.A., 1986, Arsenic(III) oxidation and removal from drinking water: U.S. Environmental Protection Agency Summary Report, EPA/600/S2-86/021, $11 \mathrm{p}$.

Fuller, C.C., Davis, J.A., and Waychunas, G.A., 1993, Surface chemistry of ferrihydrite-Part 2. Kinetics of arsenate adsorption and coprecipitation: Geochimica et Cosmochimica Acta, v. 57, p. 2271-2282.

Grosse, Douglas, Richards, Marta, Puls, Robert, Howard, Ralph, Davis, Andy, Murarka, Ishwar, and Rouse, Jim, 2000, In situ treatment of soil and groundwater contaminated with chromium, technical resource guide: U.S. Environmental Protection Agency, Office of Research and Development, EPA/625/R-00/005, 84 p.

$\mathrm{HACH}, 2000$, Method 10069, Free chlorine (high range 0 to $5 \mathrm{mg} / \mathrm{L}$ ) - Procedures Manual, DR890 Colorimeter: Loveland, Colo., Hach Company, p. 113-117.

Hem, J.D., 1985, Study and interpretation of the chemical characteristics of natural water: U.S. Geological Survey Water-Supply Paper 2254, 263 p.

Jones, C.A., Langner, H.W., Anderson, K., McDermott, T.R., and Inskeep, W.P., 2000, Rates of microbially mediated arsenate reduction and solubilization: Soil Science Society of America Journal, v. 64, p. 600-608.

Kartinen, E.O., and Martin, C.J., 1995, An overview of arsenic removal processes: Desalination, v. 103, p. 79-88.

Langmuir, Donald., 1997, Aqueous environmental geochemistry: Upper Saddle River, N.J., Prentice Hall, $600 \mathrm{p}$.

Lowry, J.D., and Lowry, S.B., 2002, Oxidation of arsenic(III) by aeration and storage: U.S. Environmental Protection Agency, EPA/600/R-01/102, 44 p.

Maurer, D.K., and Halford, K.J., 2004, Updated estimates of the distribution of average annual precipitation in Carson Valley, 1971-2000, Douglas County, Nevada, and Alpine County, California: Journal of Nevada Water Resources Association, v. 1, p. 20-39.

Maurer, D.K., Paul, A.P., Berger, D.L., and Mayers, C.J., 2008, Analysis of streamflow trends, ground-water and surfacewater interactions, and water quality in the Upper Carson River Basin, Nevada and California: U.S. Geological Survey Scientific Investigations Report 2008-5238, 192 p.

Masscheleyn, P.H., Delaune, R.D., and Patrick, W.H., Jr., 1991, Arsenic and selenium chemistry as affected by sediment redox potential and $\mathrm{pH}$ : Journal of Environmental Quality, v. 20, p. 522-527. 
Mettler, S., 2002, In-situ iron removal from ground water$\mathrm{Fe}(\mathrm{II})$ oxygenation, and precipitation products in a calcareous aquifer: Zurich, Swiss Federal Institute of Technology, Ph.D. dissertation, $146 \mathrm{p}$.

Mettler, S., Abdelmoula, M., Hoehn, E., Schönenberger, R., Weidler, P., and Von Gunten, U., 2001, Characterization of iron and manganese precipitates from an in-situ ground water treatment plant: Ground Water, v. 39 , no. 6 , p. 921-930.

Moore, J.N., Walker, J.R., and Hayes, T.H., 1990, Reaction scheme for the oxidation of As(III) to As(V) by birnessite: Clays and Clay Minerals, v. 38, no. 5, p. 549-555.

Nordstrom, D.K., and Archer, D.G., 2003, Arsenic thermodynamic data and environmental geochemistry, in Welch, A.H., and Stollenwerk, K.G., eds., Arsenic in ground water-Geochemistry and occurrence: Boston, Mass., Kluwer Academic Publishers, p. 1-25.

Oscarson, D.W., Huang, P.M., and Liaw, W.K., 1981, Role of manganese in the oxidation of arsenite by freshwater lake sediments: Clays and Clay Minerals, v. 29, no. 3, p. 219-225.

Parkhurst, D.L., and Appelo, C.A.J., 1999, User's guide to PHREEQC (Version 2)-A computer program for speciation, batch reaction, one-dimensional transport, and inverse geochemical modeling: U.S. Geological Survey Water-Resources Investigations Report 99-4259, 312 p.

Raven, K.P., Jain, A., and Hoeppert, R.H., 1998, Arsenite and arsenate adsorption on ferryhydrite-Kinetics, equilibrium and adsorption envelopes: Environmental Science and Technology, v. 32, p. 344-349.

Rott, U., 1990, Protection of groundwater quality by biochemical treatment in the aquifer, in Symposium on Groundwater Monitoring and Management, Dresden, Germany, March 1987, Proceedings: Oxfordshire, UK, International Association of Hydrological Sciences Publication no. 173, p. 383-389.

Rott, U., and Friedle, M., 1999, Subterranean removal of arsenic from groundwater, in Chappell, W.R., Abernathy, C.O., and Calderon, R.L., eds., Arsenic exposure and health effects: Oxford, UK, Elsevier Science Ltd., p. 389-396.

Rott, U., and Meyerhoff, R., 1994, Physical, chemical, and biological processes in consequence of in-situ treatment of groundwater, in Conference on Groundwater Quality Management, Tallinn, Estonia, September 1993, Proceedings: Oxfordshire, UK, International Association of Hydrological Sciences Publication no. 220, p. 439-447.
Rouse, J., Benker, E., Daud, M., Lam, D., 1999, In-situ remediation of chromium contaminated soil and ground water: Proceedings, Challenges Posed by Urban and Industrial Contaminants, Conference in Freemantle, Western Australia, sponsored by Centre for Groundwater Studies, CSIRO Land and Water, March 21-25, 1999, p. 623-631.

Shacklette, H.T., and Boerngen, J.C., 1984, Element concentrations in soils and other surficial materials of the conterminous United States: U.S. Geological Survey Professional Paper 1270, p. 105.

Stollenwerk, K.G., 2003, Geochemical processes controlling transport of arsenic in groundwater-A review of adsorption, in Welch, A.H., and Stollenwerk, K.G., eds., Arsenic in ground water-Geochemistry and occurrence: Boston, Mass., Kluwer Academic Publishers, p. 67-100.

U.S. Environmental Protection Agency, 2001a, Technical fact sheet—Final rule for arsenic in drinking water: U.S. Environmental Protection Agency, EPA 815-F-00-016, January 2001, p. 1-5.

U.S. Environmental Protection Agency, 2001b, National primary drinking water regulations; arsenic and clarifications to compliance and new source contaminants monitoring - Final rule: Federal Register, January 22, 2001, v. 66 , no. 14 , p. $6975-7066$

U.S. Environmental Protection Agency, 2008, 2006 drinking water standards and health advisories: U.S. Environmental Protection Agency, accessed September 8, 2008, at http:// www.epa.gov/waterscience/criteria/drinking.

Violante, Antonio, Del Gaudio, Stefania, Pigna, Massimo, Ricciardella, Mariarosaria, and Banerjee, Dipanjan, 2007, Coprecipitation of arsenate with metal oxides-2. Nature, mineralogy, and reactivity of iron(III) precipitates: Environmental Science and Technology, v. 41, p. $8275-8280$.

Walker, Mark, Seiler, R.L., and Meinert, Michael, 2008, Effectiveness of household reverse-osmosis systems in a Western U.S. region with high arsenic groundwater: Science of the Total Environment, v. 389, p. 245-252.

Water Research Commission South Africa, 2004, The feasibility of in-situ groundwater remediation as a robust low-cost water treatment option: Buckinghamshire, UK, Foundation for Water Research Report No. 1355/1/04, accessed July 2, 2009, at http://www.fwr.org/ wrcsa/1325104.htm. 
Welch, A.H., 1994, Ground-water quality and geochemistry in Carson and Eagle Valleys, Western Nevada and Eastern California: U.S. Geological Survey Open-File Report 93-33, $99 \mathrm{p}$.

Welch, A.H., Lico, M.S., and Hughes, J.L., 1988, Arsenic in ground water of the western United States: Ground Water, v. 26 , no. 3 , p. 333-347.

Welch, A.H., Stollenwerk, K.G., Maurer, D.K., and Feinson, L.S., 2003, In-situ arsenic remediation in a fractured, alkaline aquifer, in Welch, A.H., and Stollenwerk, K.G., eds., Arsenic in ground water-Geochemistry and occurrence: Boston, Mass., Kluwer Academic Publishers, p. 403-419.

Welch, A.H., Stollenwerk, K.G., Paul, A.P., Maurer, D.K., and Halford, K.J., 2008, In situ arsenic removal in an alkaline clastic aquifer: Applied Geochemistry, v. 23, p. 2477-2495.
White, E.L., 2009, Fallon, NV-Pooling resources to construct arsenic treatment facility: U.S. Environmental Protection Agency, accessed July 13, 2009, at http://www.epa.gov/ ogwdw000/arsenic/casestudies/pdfs/casestudy_fallon.pdf.

Zeng, H., Fisher, B., and Giammar, D.E., 2008, Individual and competitive adsorption of arsenate and phosphate to a high-surface-area iron oxide-based sorbent: Environmental Science and Technology, v. 42, p. 147-152.

Zobrist, J., Dowdle, P.P., Davis, J.A., and Oremland, R.S., 2000, Mobilization of arsenite by dissimilatory reduction of adsorbed arsenate: Environmental Science and Technology, v. 34, p. $4747-4753$. 
This page intentionally left blank. 
Publishing support provided by the U.S. Geological Survey

Publishing Network, Tacoma Publishing Service Center

For more information concerning the research in this report, contact the Director, Nevada Water Science Center

U.S. Geological Survey

2730 N. Deer Run Road

Carson City, Nevada 89701

http://nevada.usgs.gov/ 


\section{㞭}

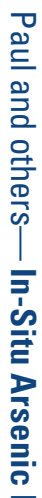

声

흠.

三'

융

产

응

के

을

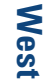

ธ்ุ

$\stackrel{9}{3}$

20

is

ก.

言

产

용.

귬

옹 